NBER WORKING PAPER SERIES

\title{
WHAT UNDERMINES AID'S IMPACT ON GROWTH?
}

\author{
Raghuram G. Rajan \\ Arvind Subramanian \\ Working Paper 11657 \\ http://www.nber.org/papers/w11657 \\ NATIONAL BUREAU OF ECONOMIC RESEARCH \\ 1050 Massachusetts Avenue \\ Cambridge, MA 02138 \\ September 2005
}

We are grateful to Simon Johnson for many useful conversations, and for helpful comments from Chris Adam, Andy Berg, Abdoulaye Bio-Tchane, Aleš Bulír, Nancy Birdsall, Francois Bourguignon, Ajay Chhibber, Michael Clemens, Tito Cordella, Shanta Devarajan, Alan Gelb, Ed Glaeser, Tim Harford, John Hicklin, Nurul Islam, Aart Kraay, Pravin Krishna, Anne Krueger, Michael Nowak, Jonathan Ostry, Alessandro Prati, Lant Pritchett, Rodney Ramcharan, Dani Rodrik, David Roodman, Shankar Satyanath, T.N. Srinivasan, Quy Toan-Do, Thierry Tressel, Alan Winters, and participants at the Center for Global Development Seminar in Washington D.C., and at seminars at Harvard and George Mason Universities. Manzoor Gill, Naomi Griffin, and Ioannis Tokatlidis provided superb research assistance. This paper reflects the authors' views and not necessarily those of the International Monetary Fund, its management, or its Board. The views expressed herein are those of the author(s) and do not necessarily reflect the views of the National Bureau of Economic Research.

(C2005 by Raghuram G. Rajan and Arvind Subramanian. All rights reserved. Short sections of text, not to exceed two paragraphs, may be quoted without explicit permission provided that full credit, including () notice, is given to the source. 
What Undermines Aid's Impact on Growth?

Raghuram G. Rajan and Arvind Subramanian

NBER Working Paper No. 11657

September 2005, Revised July 2006

JEL No. 1, 4

\title{
$\underline{\text { ABSTRACT }}$
}

We examine one of the most important and intriguing puzzles in economics: why it is so hard to find a robust effect of aid on the long-term growth of poor countries, even those with good policies. We look for a possible offset to the beneficial effects of aid, using a methodology that exploits both cross-country and within-country variation. We find that aid inflows have systematic adverse effects on a country's competitiveness, as reflected in a decline in the share of labor intensive and tradable industries in the manufacturing sector. We find evidence suggesting that these effects stem from the real exchange rate overvaluation caused by aid inflows. By contrast, private-to-private flows like remittances do not seem to create these adverse effects. We offer an explanation why and conclude with a discussion of the policy implications of these findings.

\author{
Raghuram Rajan \\ International Monetary Fund \\ Research Department, Rm 10-700 \\ 700 19th Street, N.W. \\ Washington, DC 20431 \\ and NBER \\ rrajan@imf.org \\ Arvind Subramanian \\ International Monetary Fund \\ 700 19th Street NW \\ Washington, DC 20431 \\ asubramanian@imf.org
}




\section{INTRODUCTION}

Why is there little robust evidence that foreign aid significantly enhances the economic growth of poor countries? ${ }^{1}$ For a while it appeared that we had learnt the answer; aid is frittered away by some recipient countries through corruption and mismanagement. So while on average aid does not seem to have a positive impact on growth, in countries with good policies it does (see Burnside and Dollar (2000)). Recently, however, a number of studies question this explanation. ${ }^{2}$ These studies suggest that even in countries with good policies, there is no robust association between aid and growth. The search for an alternative explanation is becoming immensely important as industrial countries are being exhorted to increase their aid budgets in order to help developing countries achieve the Millennium Development Goals.

What then could be the explanation? It may well be that resources are not everything. While schools may require textbooks or classrooms, they may also need teachers to show up regularly. By focusing on easy-to-provide resources, aid advocates may miss the harder-toprovide incentives that are critical (see Banerjee et. al., (2004) for examples in relation to education, Kremer et. al. (2004) for health-related interventions, and World Bank (2004) for illustrations of this point based on a wide variety of experiences in the developing world). While the construction of classrooms may spur economic activity in the short run, in the long run without dedicated teachers in the classroom the critical impetus that good education

\footnotetext{
${ }^{1}$ There is a voluminous literature on aid effectiveness. Important work, in addition to that cited in the text includes Alesina and Weder (2000), Bauer (1971), Collier and Dollar (2002), Dalgaard, Hansen, and Tarp (2004), Friedman (1958), Hansen and Tarp (2000), Svensson (2003), and World Bank (1998). Recently, Clemens, Radelet, and Bhavnani (2004) make the case that the some kinds of aid is indeed effective over short horizons, though Subramanian and Kumar (2005) question the findings and their robustness.

${ }^{2}$ See, for example, Easterly (2003), Easterly, Levine, and Roodman (2004), Hansen and Tarp (2001), Roodman (2004), and Rajan and Subramanian (2005).
} 
provides to growth will be missing. Nevertheless, that resources are not everything does not imply they are nothing. What offsets the undoubted benefits of additional resource flows to a resource-poor country? Also, if program design and incentive design are key, why do countries with better policies and governance not seem to use aid any better?

A second explanation is that aid has detrimental long-term effects. Even though aid resources are initially additional to the budget, eventually the country becomes more lax on raising tax revenues, and more aid is necessary just to keep the country on even keel. If that aid is not forthcoming, and if the country's tax raising mechanisms have atrophied, all the short-term beneficial effects of aid may dissipate over the long run as it creates a culture of dependency (see Azam, Devarajan, and O’Connell, 1997 and Adam and O'Connell, 1999). A related explanation is that by expanding a government's resource envelope, aid relaxes its need to explain its actions to citizens, which may have a corrupting influence even on the best intentioned of governments in the long run. In sum, aid may not have discernible positive effects in the long run because it weakens institutions, and this offsets any positive effect it may have in the short run (Knack (2001) and Brautigam and Knack (2004)).

We want to focus on a third possible explanation though. To motivate that explanation, examine Figure 1. We plot the log of the manufacturing to GDP ratio in a country against the log of the ratio of aid received to GDP for that country for two separate dates (the late 1990s and the early 1980s, separated by about 15 years), after correcting for the country's per capita PPP GDP, per capita PPP GDP squared, and country and time fixed 
effects. ${ }^{3}$ As the figure suggests, the more aid a country has received, the smaller its share of manufacturing. The coefficient estimate suggests that a 1 percentage point increase in the ratio of aid-to-GDP is associated with a reduced share of manufacturing in total GDP of about $0.2-0.3$ percentage points. ${ }^{4}$

Without further analysis, we do not know if this relationship is causal - though the simple argument for reverse causality that as a country gets poorer (and manufacturing shrinks) it gets more aid is unlikely to be the entire explanation because we correct for per capita income. Yet the relationship is striking enough to warrant further analysis. Indeed, if causal, the relationship highlighted by the chart offers an explanation for why aid may not have led to substantial growth. As pointed out by Jones and Olken (2006), and Johnson, Ostry, and Subramanian (2006), virtually all countries that have had a sustained period of growth in the post-war period have seen a large increase in their share of manufacturing and manufacturing exports.

One reason manufacturing may be so important for growth is that manufacturing is tradable. Not only could tradable sectors be the source of productivity improvements or learning, these industries, which by necessity are on the efficiency frontier, could also be a

\footnotetext{
${ }^{3}$ The residuals are obtained in a panel regression where the dependent variable is log of the ratio of the share of value added in manufacturing to GDP for a country (at two dates, the late 1990s and the early 1980s, separated by about 15 years), and the explanatory variables are the country's per capita GDP, per capita GDP squared (to allow for the U-shaped relationship postulated by Kuznets), and fixed effects for the country and the time period. All variables are averages for the period 1980-85 and 1995-2000, respectively. We focus on the period after 1980 because the coverage of the World Bank data on sectoral output increases substantially and also because the core analysis in the paper below is on the 1980s and 1990s. The sample was chosen according to the same criteria as that used for our core sample, namely, comprising countries that received aid to GDP ratio greater than 1 percent or are low income countries. The relationship depicted in the graph is robust to changes in samples and to additional controls such as the terms of trade.

${ }^{4}$ Because we include fixed effects, the association between aid and manufacturing depicted in the chart is a temporal one, that is, within countries over time rather than one between countries.
} 
strong political force pushing for sensible government policy to ensure their continued competitiveness. Their shrinkage could have wider repercussions. But why might more aid be associated with a smaller share for manufacturing? The explanation cannot be that the share of agriculture is larger: as Figure 2 suggests, we obtain a similar negative relationship when we plot the log of the ratio of manufacturing share to the share of services against the $\log$ of aid to GDP after similar corrections. This then suggests the problem may lie with the very tradability of manufacturing. If aid reduces competitiveness, then countries that receive more aid would have a lower share of (tradable) manufacturing even relative to (nontradable) services, and this could lead to lower growth.

Indeed a well-developed theoretical literature emphasizes the macroeconomic effect on a country's competitiveness of large windfalls of resources and its associated spending (also referred to in the literature as "Dutch Disease"—-see Krugman (1987), Corden and Neary (1982), van Wijnbergen (1986), and Yano and Nugent (1999) for theoretical treatments). When resources are spent on the non-traded sector, rather than on imports, it could raise the country's real exchange rate in the short run and make it harder for the country to export. If aid does not increase the supply of non-traded goods, the country's real exchange rate could be permanently higher, leading to a long-run loss of competitiveness proportional to the aid received and spent.

"Dutch Disease" offers a possible explanation of the striking relationships in the charts and, more generally, a reason why it has been so hard to find a positive effect of aid on growth. Nevertheless, the theory suggests the importance of aid-induced "Dutch Disease" is likely to be an empirical question, with even the sign of the effect of aid on the real exchange rate, and thus on competitiveness, ambiguous. 
Cross-country studies have not offered compelling evidence, one way or the other, on whether the channel is meaningful (see Adam (2005) for a comprehensive survey). Given that significant effort in the fight against poverty in coming years will be devoted to enhancing aid flows, it is of immense practical importance to attempt more direct tests of the phenomenon. This paper attempts to set the evidence on firmer footing, so that we can be better informed about how to manage aid.

There are three notable differences between our approach and that of prior empirical work. First, because Dutch Disease will have effects on the relative growth rates of tradable versus non-tradable industries in a country, we examine the within-country cross-industry variation in growth to get a more powerful test of the phenomenon. Previous studies have been at the cross-country level. By absorbing country specific variation in country indicators, we go some way in addressing the specification problem that plagues standard cross-country regressions - that some omitted country-specific variable might explain the observed correlation. We devote considerable effort to establishing the robustness of these results.

Second, we provide direct and indirect evidence on the intermediate channels from aid to exchange rates and from exchange rates to relative industry growth rates. In other words, we seek to establish that aid is the deep determinant, while identifying exchange rates as the proximate transmission mechanism.

Third, countries may get more aid if they perform particularly badly so aid is clearly endogenous to growth (though less clearly linked to relative industry growth rates). We address the issue of endogeneity by using plausibly exogenous instruments for aid.

To preview our results, we find strong evidence that aid undermines the competitiveness of the tradable sectors. In particular, in countries that receive more aid, manufacturing industries that are likely to be more affected by aid-induced Dutch Disease, namely labor-intensive and exportable industries, grow slower than manufacturing industries 
that are less likely to be affected. Furthermore, as suggested by the figures above and which we show more formally below, to the extent that aggregate manufacturing itself is more tradable than services, we find the growth of value added in manufacturing is slower in countries that get more aid.

If indeed the channel is through aid's effect on real exchange rates, we should see that: (1) aid does affect exchange rates and leads to overvaluation in our sample; (2) in countries with either a greater overvaluation of the real exchange rate or with a greater aidrelated component of overvaluation, more exposed industries grow relatively more slowly; (3) the independent effect of aid is somewhat attenuated when we include overvaluation. Indeed, this is what we see.

In sum, our work provides one reason why aid does not seem to help growth even in countries with relatively good policies -- the loss of competitiveness as aid pours in, and the consequent shrinkage of the manufacturing sector. This suggests that as aid flows ramp up, policymakers should pay particular attention to the macroeconomic management of aid inflows, to ensuring effective expenditures, and to the capacity of economies to absorb aid, if the world is not to be disappointed once again in the fight against poverty.

This paper is structured as follows. In section II, we outline our empirical strategy. In section III, we present our main results on the effect of aid on the relative growth of sectors whose competitiveness is most likely to be adversely hit, and establish its robustness. In section IV, we provide evidence that exchange rate overvaluation is the proximate channel through which aid has an effect. In section $\mathrm{V}$, we show that the effect of aid is to depress the growth of the manufacturing sector and not just a relative effect within it. In section VI, we discuss the relevant literature on aid and Dutch disease and contrast our approach with it. In section VII, we offer some concluding remarks. 


\section{AID AND GROWTH: A CHANNEL}

\section{A. Theory}

We focus on an important reason why aid could hurt growth - that it reduces the competitiveness of the traded goods sector and results in a re-allocation of resources away from it and towards the non-traded sector. There are at least two possible channels through which this might work, depending largely on the exchange rate regime. First, aid inflows could push up the price of some critical resources that are common to both the traded and non-traded goods sectors. For example, aid could be spent on fees to contractors, as well as salaries to engineers, doctors, teachers, civil servants, and aid administrators. Because the non-traded goods sector (or the social sector) does not have external competition, it can raise output prices to compensate for the higher wages. But if the tradable sector competes in the same pool for its managers and foremen, then this sector whose output prices are fixed by foreign competition will lose competitiveness and profitability.

The second channel is that in a flexible exchange regime, aid inflows may also push up the nominal exchange rate (for example when the central bank sells the aid inflows in the domestic foreign exchange market), rendering the traded goods sector uncompetitive if wages in that sector do not adjust downwards. These two effects are not mutually exclusive - they lead to the same ultimate effect of a real exchange rate appreciation. Another way of putting it is that in either case, the traded sector becomes uncompetitive and shrinks, but whether this happens in a more or less inflationary environment for wages and prices depends on the exchange rate regime.

Aid inflows do not make these effects inevitable. The more aid is spent on traded goods or factors (imported capital goods, foreign consultants) and on factors that are not in limited supply (unskilled labor), the more the supply of factors and non-traded goods respond to aid inflows, and the more domestic fiscal contraction takes place, the less likely will wages 
and prices be bid up to an excessive degree and the less likely will the real exchange rate appreciate (see Berg et al. (2005)). Thus whether aid reduces competitiveness by pushing up the real exchange rate is indeed an empirical question.

The following schematic representation of the effects of aid on prices and quantities will make clear the hypothesis in this paper.

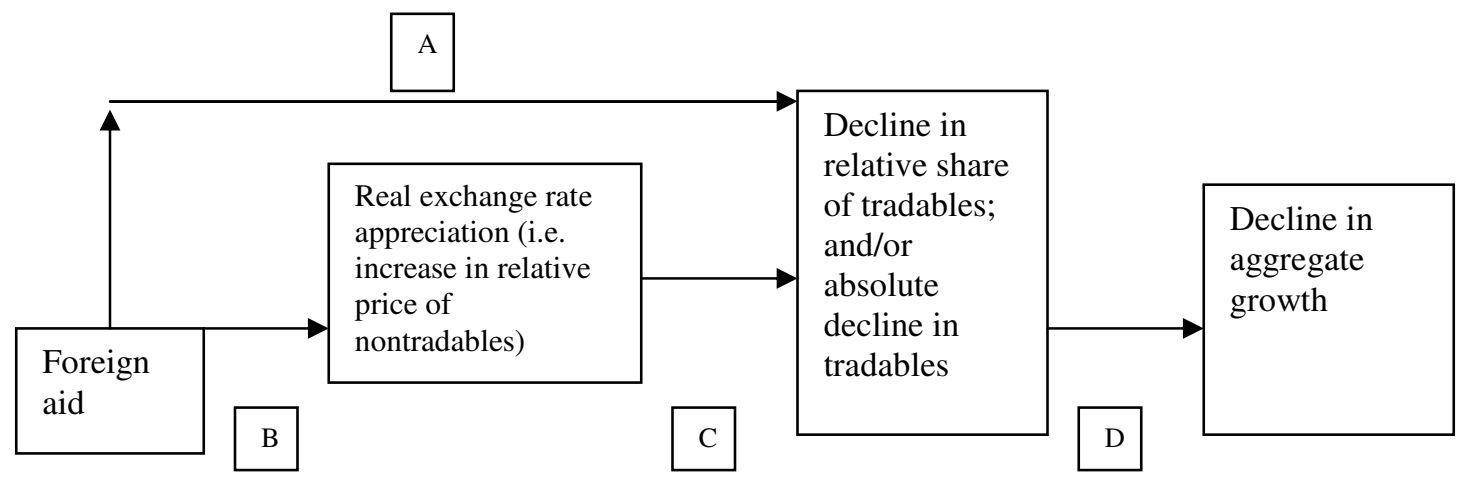

Simply put, we hypothesize a relationship from aid to the growth of the tradable sector (channel A) which in turn could have adverse consequences for long-run aggregate growth (channel D). Channel A can in turn be broken down to two mediating channels: from aid to exchange rates $(\mathrm{B})$ and from exchange rates to the growth of the tradable sector $(\mathrm{C})$.

This paper will mainly be devoted to channels A, B, and C. We will not spend much time on channel D, taking as largely given the fact that growth in the tradable sector is a close correlate, if not a prerequisite, of overall growth.

\section{B. Empirical Strategy}

We use the methodology in Rajan and Zingales (1998) to test the hypothesis that aid might reduce the competitiveness of the traded goods sector. They suggest that one way to check whether a channel is at work is to see whether industries that might be most affected by a channel grow differentially (faster or slower depending on the nature of the effect) in countries where that channel is likely to be more operative. The industry characteristic we are interested in is the degree to which an industry's competitive position is affected by 
overvaluation, the channel is real exchange rate overvaluation, and countries that get more aid are likely to be the ones where the channel is most operative. The estimation strategy is then to run regressions of the form:

Growth $_{i j}=$ Constant $+\zeta_{1 \ldots . . m} *$ Country Indicators $+\zeta_{m+1 \ldots . n} *$ Industry Indicators + $\zeta_{n+1} *($ Industry $i$ 's share of manufacturing in country $j$ in the initial period $)+$ $\alpha$ (Aid to country $j^{*}$ Sensitivity of industry $i$ to Dutch Disease $)+\varepsilon_{i j}$

where Growth $\mathrm{ij}_{\mathrm{j}}$ is the annual average rate of growth of value added of industry $\mathrm{i}$ in country j over a ten-year period, obtained by normalizing the growth in nominal value added by the GDP deflator; $\zeta_{1 \ldots . . m}$ are the coefficients of the country fixed effects; $\zeta_{\mathrm{m}+1 \ldots \mathrm{n}}$ are the coefficients of the industry fixed effects; $\zeta_{n+1}$ is the coefficient of the initial period share of industry $\mathrm{i}$ in total value added in country $\mathrm{j}$ (which controls for convergence-type effects); Aid to country $\mathrm{j}$ is the average aid to GDP ratio for that country over the sample period. The coefficient of interest for us is $\alpha$. It captures an interaction between a country-specific aid variable and an industry's sensitivity to the debilitating effects of Dutch Disease. We posit that countries that receive more aid should see a more negative impact in industrial sectors that are more sensitive, so that we would expect the coefficient $\alpha$ to be negative.

The chief advantage of this strategy is that by controlling for country and industry fixed effects, the problem of omitted variables bias or model specification, which seriously afflicts cross-country regressions, is diminished. Essentially, we are making predictions about within-country differences between industries based on an interaction between a country and industry characteristic. Moreover, because we focus on differences between manufacturing industries (rather than between, say, manufacturing and services industries), we can rule out factors that would keep manufacturing underdeveloped as explanations of our results - for these factors should not affect the differences between manufacturing industries. 


\section{Implementing the Strategy}

However, this focus on manufacturing only (driven also by data availability) comes at a cost. The manufacturing sector, by and large, is tradable. So how do we develop a proxy for the sensitivity of an industry to Dutch disease?

One way forward is to note that if Dutch disease "works" through an increase in real wages, then industries that have relatively higher labor costs should be affected more. We measure labor costs (which we can also call labor-intensity) as the average across the countries in our sample of the share of labor compensation to value-added in each industry. As can be seen in Appendix Table 1c, wearing apparel, printing and publishing, and machinery (except electrical) score high on labor intensity.

Another approach is to recognize that in a poor developing country, the lack of competitiveness is likely to show up to a greater extent in exports, than in import-competing industries. This is in part because, during the time-period under study, government action to support import-competing industries if the exchange rate were overvalued (for example, through import tariffs and non-tariff barriers) was easier for poor governments than actions to support exporting industries (for example, cash or tax subsidies). Our proxy for exportability is an indicator variable for each industry, which takes the value 1 if the industry has a ratio of exports to value added (averaged across all countries in the sample) greater than the median across industries. ${ }^{5}$ The indicator takes the value zero otherwise. We call this indicator "exportability."6

Of course, not all exports are likely to be subject to Dutch Disease. In particular, exports of extractable resources where labor intensity is low are unlikely to be affected by an

\footnotetext{
${ }^{5}$ We obtained these data from Nicita and Olarrega (2001).

${ }^{6}$ By discretizing our index we lose some information, but we also eliminate noise in classification. We also stay closer to the notion that either a product is exportable or it is not.
} 
overvalued real exchange rate. Fortunately, by focusing on manufacturing, we largely exclude such industries. Nevertheless, we also examine if the results are robust to our dropping "Petroleum refineries" and "Misc. petroleum and coal products", two industries that have high exportability, low labor intensity, and are based on extractable resources.

In sum, we will use "labor intensity" as our primary measure of the degree of exposure of industries to Dutch Disease and "exportability" as an alternative which will allow us to check robustness. The correlation between the labor-intensity and exportability is 0.34, suggesting that they are capturing similar things. Indeed, insofar as developing countries have a comparative advantage in labor-intensive sectors, our measure of laborintensity is also likely to be a proxy for exportables. But they are not exactly the same-for instance, printing and publishing which has high labor intensity has low exportability. Because we examine growth differentials between industries within countries, the results are less sensitive to the rationale for why aid is given. For example, even if aid is given only to countries that display poor growth, inter-industry growth differentials should not be seriously affected. However, suppose low growth is primarily because countries have overvalued exchange rates, and aid is systematically given to countries that have more overvalued exchange rates. In this case, we might be attributing to aid what is actually driven by trade and exchange rate policies. One way to address this is to correct directly for policy, which we do. Another is through instrumentation, which allows us to disentangle the direction of causality. 


\section{Instrumentation Strategy}

We instrument for aid based on strategic, historic, and cultural links between donor and recipient. ${ }^{7}$ We exploit the fact that aid is often extended for non-economic reasons. Our main identification assumption is that non-economically-motivated aid is unlikely to be driven by economic outcomes. This notion is far from new. A number of papers have used this to explain aid flows (Alesina and Dollar, 2001; and Barro and Lee, 2004). But we are not aware of papers that have taken the obvious next step of exploiting it to systematically develop instruments for aid which could be used in aid-growth analyses.

We derive our aid instruments along the lines of Frankel and Romer (1999). Our basic model is as follows. Once a donor d decides on a total quantum of aid, it allocates it to a recipient $\mathrm{r}$ using the following equation:

$$
\begin{aligned}
& \theta_{d r t}=\beta^{\prime} Y_{d r t}+v_{d r t} \\
& =\beta_{0}+\beta_{1} \text { STRAT }_{d r t}+\beta_{2} \text { USISEG }_{d r t}+\beta_{3} \text { COMCOL }_{d r}+\beta_{4} \text { COMCOLUK }_{d r}+\beta_{5} \text { COMCOLFRA }_{d r} \\
& +\beta_{6} C_{C O M C O L S P A} d r+\beta_{7} C O M C O L P O R_{d r}+\beta_{8} C U R C O L_{d r t}+\beta_{9} C O M L A N G d r+v_{d r t}
\end{aligned}
$$

where $\theta_{d r t}$ is the share of donor country d's aid allocated to recipient $\mathrm{r}$ in year $\mathrm{t}$, and $\mathrm{Y}$ is the vector of explanatory variables that capture different (non-economic) aspects of donorrecipient relationships. ${ }^{8}$ The variables include: STRAT takes on a value of 1 if the donor and recipient are common members of, or signatories to, an Entente or Alliance in any given time

\footnotetext{
${ }^{7}$ Given the rationale for instrumenting, all we need are predetermined instruments that correlate with aid but not with a country's policies. We do not need to ensure our instruments are uncorrelated with aggregate growth.

${ }^{8}$ In order to estimate equation 1 , we need to compute the share of a country's total (i.e. bilateral and multilateral) aid that goes to any particular recipient. To do this, we obtain a decomposition of multilateral aid into its underlying bilateral constituents. The OECD DAC database contains a series called "imputed" bilateral aid, which does precisely this.
} 
period $;{ }^{9}$ USISEG takes on a value of 1 for US-Egypt and US-Israel observations after the Camp David agreement; COMCOL a value of one if the recipient was ever a colony of the donor, COMCOLUK, COMCOLFRA, COMCOLSPA, and COMCOLPOR refer in turn to colonial relationships involving respectively the U.K. France, Spain and Portugal); CURCOL a value of one if there is a contemporaneous colonial relationship between donor and recipient; and COMLANG is a dummy that takes a value of one if the donor and recipient share a common language. A key identifying assumption is that the right hand side variables proxy for reasons for giving aid that are uncorrelated with the recipient country's economic performance. The data to estimate these equations are discussed in Appendix $1 .^{10}$

The predicted share $\hat{\theta}_{d r t}=\beta^{\prime} Y_{d r t}$ (where $\mathrm{Y}$ are the regressors in matrix notation) is then used to calculate the (instrumented) aid to GDP ratio received by country $r$ in year $\mathrm{t}$ as follows:

$$
\hat{A}_{r t}=\frac{\sum_{d} G D P_{d t} A_{d t} \cdot \hat{\theta}_{d r t}}{G D P_{r t}}
$$

where $G D P_{d t}$ is the GDP of the donor country d in dollars in year $\mathrm{t}$ and $A_{d t}$ is the Aid to GDP ratio for that donor country in that year. $\hat{A}_{r t}$ averaged over the relevant period will be the

\footnotetext{
${ }^{9}$ In the Correlates of War database from which these data are obtained, there are 4 types of alliances: a common alliance; a defense alliance; a neutrality or non-aggression alliance; and an entente alliance. We use the last as it seems the most consistent with the strategic ties we are interested in.

${ }^{10}$ So, our construction of instruments starts from the bilateral (donor-recipient) relationship and aggregates up. This is in contrast to the literature that pick instruments directly at the level of the recipient country.
} 
instrument we use in much of the paper for aid. ${ }^{11}$

\section{E. Data and their Sources}

The data and their sources are described in detail in Appendix 1. The data for industry value added growth comes from the Industrial Statistics Database (2003) of the United Nations Industrial Development Organization (UNIDO). The data are at the 3-digit level of the International Standard Industrial Classification of All Economic Activities (ISIC, Revision 2) and are available for the 1980s and 1990s.

In order to keep the sample as large as possible without compromising our focus on long-term growth, we include all those industry observations where the average growth rate can be computed over at least a seven-year period in the decade. On this criterion, the UNIDO database has data for 47 developing countries for the 1980s and 31 countries for the 1990s.

But our methodology is most applicable when we include broadly similar countries with roughly similar levels of technological endowments. Therefore, we want to exclude, but using an objective criterion, richer emerging market countries such as Malta, Cyprus, Hungary, Korea, Kuwait, and Singapore and focus on the poorer ones. At the same time, we do not want to exclude recipients of significant aid. Our final sample therefore comprises countries that receive aid greater than 1 percent of GDP or are low-income countries according to World Bank definitions in the initial year of the sample. Our sample then has 33

\footnotetext{
${ }^{11}$ One major concern with our instrumenting variables (strategic variables, colonial relationships, and proximity to donors etc.), is that they induce or are correlated with some country-specific attribute: for example, proximity (geographical and strategic) to donors might be bad because donors require bad policies or support bad leaders or require greater defense-related spending. Alternatively, proximity to donors might be good because they impose good conditionality. Also, certain colonial relationships may imply a certain quality of current institutions with impacts on growth. In our framework, however, any impact on country-specific attributes is absorbed in the country fixed effects. It is harder to see why relationships with donors should systematically affect growth in particular industrial sectors.
} 
countries for the 1980s and 15 countries for the 1990s. The UNIDO database contains data on 28 industries in these countries. ${ }^{12}$

In Table 1, we present means, medians, and standard deviations for the key variables in the analysis. The median growth rate of value added for industries is 1.5 percent for the decade 1980-90 and 3.7 percent for 1990-2000. The average aid inflow into the 33 countries in the 1980-1990 sample is 5.8 percent of GDP and the average aid inflow into the 15 countries in the 1990-2000 sample is 5.0 percent of GDP. The average labor intensity of industries is about 40 percent and 36 percent in the two decades, respectively. In much of the paper we will focus on the results for the 1980s because our sample is twice as large (33 countries and 712 observations) as for the 1990s (15 countries and 357 observations). But the results and robustness checks that we present for the 1980s are qualitatively similar for the 1990s (see the working paper version). ${ }^{13}$

One concern, given that a number of countries are not covered by the UNIDO database, is whether the countries in our sample differ from the typical aid recipient. Comparing the core 1980s sample that we use in this paper with a larger sample (comprising all countries selected on the same criteria as in this paper and for which manufacturing data are available in the World Bank's World Development Indicators), we find countries in our sample receive moderately less aid $(5.6 \%$ relative to $7.0 \%)$ and grow somewhat faster (GDP growth $1.0 \%$ vs $0.7 \%$, manufacturing growth $4.8 \%$ vs $3.6 \%$ ). Countries in our sample are neither considerably worse in performance, nor indeed very different from the larger sample.

\footnotetext{
${ }^{12}$ Appendix 1 lists all countries for which data were available as well as those countries that were included in the econometric analysis.

${ }^{13}$ The limited availability of data for the 1990s militates against panel estimations. Indeed, if we formed a panel, the set of countries for which we had data for the 1990s and 1980s would only be 14 .
} 
The variation in our sample on these indicators is also not very different (see Appendix Table 1D). Prima facie, there is little to suggest our sample is "special."

\section{AID And Sensitivity To Dutch Disease}

\section{A. The Core Specification}

We present our core specifications in Table 2, Panel A for the 1980s corresponding to the relationship depicted as channel A in the schema in Section II.A. In column 1 we report the OLS estimate, in column 2 the "reduced form" OLS estimate in which the instrument for the aid term is entered directly in the second-stage regression instead of the aid term itself, and in column 3, the IV specification where aid is instrumented. In all cases, the labor intensity interaction term is negative and statistically significant at the 5 percent confidence level. The value added by labor-intensive industries grows relatively more slowly than for other industries in countries that receive more aid. It is worth noting that our core result does not depend on instrumentation, although instrumentation increases the magnitude of the measured interaction effect. ${ }^{14}$

What can we say about magnitudes? Since all the regressors are normalized, the interaction term measures the impact of a one standard deviation increase in aid in country $\mathrm{j}$ and a one standard deviation increase in the labor intensity of the industry on the growth rate of industry $\mathrm{i}$ in country $\mathrm{j} .{ }^{15}$ Take 2 countries, Zambia and Honduras that are roughly one

\footnotetext{
${ }^{14}$ In Table 2, Panel B, we present our first-stage results corresponding to the core specifications for the 1980s. The instrument is very precisely estimated (the coefficients are always significant at the 1 percent level), corresponding to an F-statistic of 23.5, which is large, comfortably exceeding the Staiger-Stock (1997) threshold of 10 for strong instruments.

${ }^{15}$ The standard errors in the second-stage regressions can be corrected to take account of the fact that the instrument used in the first-stage is estimated. We used the the procedure in Frankel and Romer (1999) to check if this correction led to significant changes and found that it did not.
} 
standard deviation (about 4.2 percentage points) apart in terms of aid to GDP. And take 2 industries, apparel and rubber products that are also about 1 standard deviation (about 8.4 percentage points) apart in terms of their labor share. Using our core IV specification in column 3, the apparel sector should grow 3.5 percent per year slower relative to glass and products in Zambia than in Honduras. This is quite substantial when compared with the average growth rate in the sample of 1.8 percent.

We depict this core result in a non-parametric form in Chart 3. We divide the industries into two groups (above- and below-median) depending on their labor intensity. Next we estimate for each country the difference in average growth in annual value added between above- and below-median industries. We plot this difference against the aid-toGDP received by each country. Chart 3 shows that the difference in growth is negatively related to the aid received by a country, and no single country drives it.

\section{B. Robustness to Time Periods, Sample, and Measures of Aid}

We subject the core IV results in Table 2 to a number of other robustness checks. In Table 3, we check for robustness to time periods. So we reproduce Table 2 for the 15 countries for which we have data for the 1990s. Our results remain unchanged, although the magnitude of the aid-labor intensity interaction is slightly reduced. And in Panel B, the results confirm that our instrument remains strong (an F-value of over 50, sufficiently high to ensure we do not have a problem with weak instruments). ${ }^{16}$

In Table 4, we check for robustness to samples. In column 1, we exclude outliers, and the coefficient is still negative and significant. Since the datasets are inherently noisy, we check whether "winsorizing" makes a difference. In column 2 we set all values of the left and right hand side variables that are above (below) the value of the $99^{\text {th }}\left(1^{\text {st }}\right)$ percentile to the

\footnotetext{
${ }^{16}$ We would note here that the robustness results that we report below hold for the 1990s sample (see the working paper version) as well.
} 
value of the $99^{\text {th }}\left(1^{\text {st }}\right)$ percentile observation. In column 3 , we do the same, but at the $95^{\text {th }} / 5^{\text {th }}$ percentile. In column 4, we exclude three countries-Israel, Poland, and Thailand-- that might be considered different from the rest of the sample. The coefficient estimate for the interaction is significant and broadly unchanged in magnitude across the columns.

In addition to these checks, we perform a battery of tests, involving the deletion of one country and one industry at a time (available from the authors upon request). For the 1980s, this amounts to checking robustness to 60 different sub-samples and to 43 different sub-samples for the 1990s. In all (103) cases, the coefficients were statistically significant, with coefficient values remaining broadly unchanged. This is reassuring about the robustness of our core result.

In Table 5, we perform other robustness checks. In column 1, we restrict the sample to countries whose labor-intensity values are highly correlated, industry by industry, with the average across countries, ${ }^{17}$ and in column 2 , we use initial rather than contemporaneous labor shares. In column 3, we check if our results are robust to using an alternative instrument for aid; in our core specifications in Table 2, the instruments exploit only one source of exogenous cross-country variation, namely the traditional or strategic relationships between donors and recipients of aid. In column 3, we exploit an additional source of exogenous variation, namely the donor's budgetary position which determines how much aggregate aid it can give, in devising the instrument (see Appendix 2 for details). The results are qualitatively similar to our core result in all cases.

\footnotetext{
${ }^{17}$ This procedure may drop the countries in which labor is most distorted, either because of aid flows themselves pushing up wages and moving labor intensity away from the average or because of other distortions. This is why one cannot use such correlations to examine whether the maintained assumption of a technological propensity to use labor is valid across countries. However, it is a useful robustness check.
} 
In columns 4 and 5, we present results based on clustering of the standard errors, first by industry then by country. Essentially, this recognizes that observations may not be independent. The coefficient estimates continue to be significant, with the standard error increasing only slightly.

So far our measure of aid has been total aid. We need to check whether our results are robust to alternative definitions of aid, and whether there is any pattern when we do so. In particular, aid should have less of an impact on domestic wages or on the exchange rate the more it is spent on imports. Ideally, if we could measure ex ante the import-intensity of the usage of different types of aid, we could test whether the coefficient on the aid-labor intensity interaction term varies according to the type of aid. In practice, it is very difficult to do this, not least because aid is fungible. However, there seems to be a widely shared view that technical assistance is very import-intensive because it largely goes as payments to foreign consultants. We exploit this fact by testing whether the adverse competitiveness effect is mitigated in the case of technical assistance.

In column 1 of Table 6 , we use a measure of total aid without the technical assistance component. We continue to find evidence of a negative impact on labor-intensive industries. And, consistent with our prior that technical assistance is more import-intensive, the magnitude of the coefficient is larger than in the core specification (-4.1 percent compared to -3.5 percent). In column 2 , we introduced technical assistance as the aid measure and find that the coefficient, though still negative and significant, is smaller in absolute value $(-2.6$ percent). Nevertheless, the coefficient is still negative and significant, which may, in part, be explained by the fact that technical aid may proxy for all forms of aid or that there is fungibility between types of aid.

Clemens et al. (2004) argue that one should distinguish between aid meant to produce results in the short term, and aid meant to produce results in the long term. From our 
perspective, however, the horizon over which spending should have effect is immaterial, what matters is when spending occurs. This then offers a natural robustness check of our results. Using the Clemens et al. database, which the authors kindly shared with us, in column 3 we include aid that is likely to have impact in the short term and in column 4, aid that is likely to have an impact in the long term. In both columns, the estimate of the interaction term is negative and is statistically significant. These results suggest that while there may be some differences in the impact depending on the type of aid, all forms of aid yield the same robust result of an adverse competitiveness effect.

\section{Robustness to Outcome Measures}

The share of nominal value added of an industry in nominal manufacturing value added reflects its economic importance - its share of value created at market prices. Given that common deflators like a GDP deflator or the growth rate of the manufacturing sector are absorbed by the country fixed effect, our dependent variable could also be seen as the growth in a sector's nominal share. If the external sector's indirect contribution to economic growth (through increases in productivity and increases in foreign exchange earnings) depends on its nominal share, then this is the dependent variable we want to focus on for our analysis.

However, it is also interesting to examine the growth in real value added. This poses a special problem: the increase in nominal value added in each sector is composed of two parts; the increase in real value added and the increase in output prices in that sector. We have already argued that if the effect we have hypothesized is at work, aid increases the rate 
of output price increases in the non-traded, capital-intensive industries relative to the traded, labor-intensive industries. This means that if we want to compute the growth in real valueadded in an industry, we have to deflate nominal growth in that industry by a industryspecific price deflator, rather than the country-wide, industry-invariant GDP deflator.

Unfortunately, we do not have an industry-specific price index. So, we look at two other measures of real activity, employment and industrial production. In Table 7, column 1 the dependent variable is average annual employment growth in an industry in a country, and in column 2 it is the index of industrial production. The aid interaction term has the predicted negative sign in both cases and is significant.

\section{Robustness to Measure of Sensitivity to Dutch Disease}

We want to establish that our results are robust to other measures of sensitivity to Dutch disease. As we argued earlier, variation in labor-intensity allows us to test whether the wage channel associated with Dutch disease is at work. An alternative way of testing for Dutch disease is to see whether export sectors are differentially affected by aid.

In Table 8, we present another set of core specifications with labor intensity replaced by the exportability index. In column 1 we report the OLS estimate, in column 2 the "reduced form" OLS estimate in which the instrument for the aid term is entered directly in the second-stage regression instead of the aid term itself, and in column 3, the "pure" IV specifications. In all cases, the aid-exportability interaction term is negative and statistically significant at the 5 percent confidence. That is, exportable industries grow slower in countries that receive more aid.

As discussed earlier, some exportables, such as commodity exports that require little labor intensive processing, may not be much affected by Dutch Disease. Amongst our 
industries, "petroleum refineries" and "petroleum and coal products" stand out as two commodity-based exports that have low labor intensity. If we exclude these two industries from the dataset, the IV estimate of the interaction goes up in magnitude as one might expect, and it remains significant (available from the authors).

Finally, the robustness checks that we report for the core sample in Sections III.B and III.C above are also substantially borne out when we use the exportability indicator rather than labor intensity as our measure of susceptibility to Dutch Disease (available upon request). ${ }^{18}$ Thus, our results do not seem overly dependent on a particular measure of a sector's vulnerability to aid-induced Dutch Disease. Given that neither proxy is ideal, this is reassuring.

\section{The Transmission Mechanism From Aid to SeCtoral GroWTH}

To summarize, we have shown the link between aid and the relative growth of the labor-intensive and exportable industries. We claim that this arises because of the effect of aid on the real exchange rate, which in turn adversely affects the labor-intensive and exportable industries. This then leads to the natural question: how can we be sure that our core result does indeed reflect such an overvaluation effect and what is the connection between aid and overvaluation? To answer these questions we can bring to bear more evidence, direct and indirect, relating to real exchange rate overvaluation.

\footnotetext{
18 The one exception is the regression corresponding to Table 7 , column 2 , where the coefficient on the aid exportability interaction is statistically insignificant.
} 


\section{A. Does aid "Cause" Overvaluation?}

If overvaluation is the channel, then overvaluation, like aid, should particularly affect exportable and labor intensive sectors. In other words, in countries with more overvalued exchange rates, exportable and labor-intensive sectors should grow relatively slower than other sectors. We therefore estimate equation 1 above with the difference that we replace the aid variable with a measure of overvaluation due to Easterly and Levine (2003) which is based on updating Dollar (1992). ${ }^{19}$ We report the results in Table 9A.

In column 1, we estimate using OLS. The coefficient estimate for the interaction is negative and statistically significant. Clearly, if slow growth draws in aid, which in turn causes overvaluation, we have a problem of endogeneity. Fortunately, we already have the means to deal with it. The component of overvaluation stemming from exogenous aid flows is likely to be exogenous. This then calls for instrumental variable estimation where we use fitted aid (using the instruments described earlier) interacted with labor share in explaining the degree of overvaluation interacted with labor share in the first stage, and use the predicted interaction in the second stage.

In Table 9B, we present the results of the first-stage regressions of overvaluation on the instrument for aid. In column 1, which is the first-stage corresponding to the second stage in Column 3 of Table 9, the dependent variable is overvaluation times labor share and the explanatory variable is fitted aid times labor share. The coefficient on the instrument is positive and significant at the 1 percent confidence level (t-value of 3.4), as predicted.

${ }^{19}$ Dollar (1992) computed exchange rate overvaluation as the deviation of a country's price level relative to the US from its equilibrium level, which is related to a country's income level. Specifically, he regressed a country's price level on its per capita PPP GDP and its square along with an indicator for sub-Saharan Africa and Latin America, and used the residual as the measure of real exchange rate overvaluation. Easterly and Levine (2003) update this data for the 1990s. A value of 1 on the index signifies no under-or over-valuation, with increases representing more overvaluation. 
The second stage or IV result (Table 9A, column 3) suggest that the component of overvaluation caused by exogenous aid inflows does hurt competitiveness. The pattern of the interaction coefficients is also similar to those in Tables 2; that is, the IV estimations yield significantly greater coefficients than OLS estimations.

In columns 4, 5 and 6, we repeat this exercise replacing the labor-intensity measure with the exportability indicator. Again, in OLS, reduced form, and IV variants, the coefficient is significant, albeit at the 10 percent level. As a further robustness check, we use an alternative measure of overvaluation, which we compute based on Frankel (2004) and we get similar results (estimates presented in the working paper version). ${ }^{20}$

We have just established that exchange rate overvaluation, especially that caused by exogenous aid, has a similar effect as aid on industries sensitive to Dutch Disease. Another way to check this is to introduce both the aid and overvaluation interactions in the same regression. If aid is indeed the deep causal determinant, and overvaluation the main mediating channel, we should find that the direct effect of the aid interaction should be attenuated in the presence of the overvaluation interaction. ${ }^{21}$ In Column 1 of Table 10, when we introduce both aid and the overvaluation term, both interacted with the labor intensity measure, we find that the coefficient estimate for the overvaluation interaction is significant but that for the aid interaction drops in magnitude and ceases to be statistically significant, suggesting that aid and overvaluation represent the same channel. Of course, one caveat in interpreting this exercise is that we cannot instrument either interaction because we have only one instrument.

${ }^{20}$ This method is similar to Dollar (1992) except that we do not use region fixed effects or the squared per capita PPP GDP term in the long run price level equation.

${ }^{21}$ In two different contexts, Banerjee and Iyer (2005) and Acemoglu et. al. (2003) rely on similar arguments and a similar econometric specification to establish the mediating channel for their deep determinants. 


\section{B. Is the Overvaluation a Reflection of other Policies Rather than Aid?}

Is the observed significant estimate for the aid labor intensity interaction a proxy for other policies than aid? Consider trade reform. It is well-known that trade reform alleviates the anti-export bias of a regime. Is it possible that countries are poor because they have bad trade policies, and this, not aid, is responsible for the pattern of industry growth we observe? Indeed, could restrictive trade policies themselves be responsible for the observed overvaluation (see, for example, Bhagwati and Desai (1973) or Krueger (1975)) One way to test this is to include an interaction between the strength of trade liberalization policies and labor intensity. If the trade reform interaction swamps the aid interaction, we would have less confidence that aid causes the differential growth patterns we observe.

In Table 10 column 2, we include the Sachs-Warner measure of trade reform interacted with the labor intensity measure. We find that the coefficient on the trade policy interaction is insignificant but the aid interaction is relatively unchanged in magnitude and statistical significance.

In a similar vein, one could argue that exchange rate mismanagement and distortions result in slow growth, aid inflows, and the observed relative growth patterns of industries. In column 3, we use a measure of the black market premium (from Reinhart and Rogoff (2003)) instead of the trade policy measure, and obtain similar results. ${ }^{22}$ Hence, the results in columns 2-3 suggest that it is aid rather than trade or macroeconomic policies that are "causing" exchange rate overvaluation, reinforcing the message obtained from instrumentation.

${ }^{22}$ Rodriguez and Rodrik (1999) argue that both the Sachs-Warner and black market premium measures are measures not just of trade policy but of broader macroeconomic stability. 


\section{Is it Resources Provided by Aid Rather than Aid-induced Overvaluation?}

The next step is to show that aid does not affect sectoral growth through channels other than overvaluation. One alternative explanation of the basic interaction between labor intensity and aid is that industries with a high need for capital (and thus lower labor share) grow relatively faster as a country receives aid inflows. This would be a relatively benign explanation of our basic findings, suggesting that aid relieves financing constraints and increases the overall resource envelope. ${ }^{23}$

There are three reasons why this is an unlikely explanation. First, as we will show below, the effect of aid on the average growth of manufacturing industries in a country is negative, not consistent with the benign "aid is financing" explanation. Second, we have also seen the adverse effects of aid on the relative growth rates of labor intensive industries comes through an overvaluation of the real exchange rate. Again, this is inconsistent with the benign explanation.

Third, if the capital-enhancing channel is at work (rather than the real-exchange-rateovervaluation channel), countries that receive more aid should see an increase in the output of industries that are more dependent on external financial resources. To control for any possible effect of aid in alleviating financing constraints, we include the interaction of aid inflows with the Rajan and Zingales (1998) variable that measures the dependence of a particular industry on external resources to finance investment. Thus, if aid increases the resource envelope available to the industrial sector, we should expect the coefficient of this interaction term to be positive. Moreover, if the availability of capital rather than labor

\footnotetext{
${ }^{23}$ The simplest example of aid providing more resources to the private sector would be one where the government reduces its borrowing from the banking system in response to the aid, and hence makes more credit available to the private sector.
} 
intensity is what matters, the coefficient on the labor intensity-aid interaction term should fall in magnitude when we include the financial dependence-aid interaction.

In Table 10, column 4, we estimate the coefficient of the aid financial dependence interaction separately and together with the aid labor intensity interaction in column 5. Only the labor intensity interaction is statistically significant (and negative). Therefore, it does not appear that the channel through which the relative growth rates are affected by aid is via capital-intensive sectors getting increased access to resources. The magnitudes of the aidlabor interaction coefficient is similar to that estimated in column 3 of Table 2, suggesting that labor intensity is not an indirect proxy for resource intensity. ${ }^{24}$

Finally, we repeat the exercise just conducted with exportability instead of labor share as the measure of sensitivity to Dutch Disease (Table 10, cols 6-9). As can be seen, the only significant difference is that when the aid exportability interaction and the overvaluation exportability interaction are both included, it is the latter that loses significance (see col. 6), even though both coefficient estimates shrink in magnitude. ${ }^{25}$ Again, given the earlier caveat, the main takeaway is that the two interactions represent similar effects.

By contrast, when we introduce the policy exportability interaction (col 7), even though the coefficient of this interaction is positive and significant (countries with more liberal trade policies have more growth in typically exportable sectors), the coefficient of the

\footnotetext{
${ }^{24}$ Another proxy for reliance on external finance may be the average size of establishments, with small (and thus young) establishments requiring more external finance than large establishments. When we include the average size of establishments in an industry in a country interacted with aid inflows, the coefficient for the labor intensity aid interaction still remains unchanged (estimates available from the authors).

${ }^{25}$ When we drop the petroleum related industries, coefficient estimates for both interactions are significant but shrunken in magnitude. Again, the implication is that they proxy for similar channels.
} 
aid exportability interaction remains negative and significant, and relatively unchanged in magnitude. Thus these interactions represent different effects, in contrast to the earlier ones.

\section{RElative OR AbSOLUTE EFFECTs?}

The difference-in-difference methodology only allows us to measure relative growth rates of different sectors. Specifically, our result shows that labor-intensive and exportable sectors grow slower than capital-intensive and domestic-oriented sectors in countries receiving aid. Coupled with the other checks we have provided, this offers plausible evidence that the channel we have postulated - exchange rate overvaluation as a result of aid inflows is at work. We believe this is a step forward in the literature. However, our methodology thus far does not allow us to say whether aid merely causes a relative slowing of labor-intensive sectors or whether aid depresses the overall growth of the manufacturing sector. To see this more clearly, consider the basic model represented in equation 1.

Growt $_{i j}=$ Constant $+\zeta_{1 \ldots . . m} *$ Country Indicators $+\zeta_{m+1 \ldots . . n} *$ Industry Indicators + $\zeta_{n+1} *$ (Industry $i$ 's share of manufacturing in country $j$ in the initial period) $+\alpha$ (Aid to country $j^{*}$ Sensitivity of industry $i$ to Dutch Disease $)+\varepsilon_{i j}$

The derivative of growth in industry $\mathrm{i}$ in country $\mathrm{j}$ with respect to aid is not $\alpha$ times tradability (i). It is $(\theta+\alpha$ labor-intensity $(i))$ where $\theta$ is an unidentified effect of aid on the overall growth rate of industries in a country, which is absorbed in the country fixed effects, $\zeta_{1 \ldots . . . m}$. Our results thus far shed no light on $\theta$, so we cannot sign the impact of aid on the total growth of tradable sectors, only on their relative growth.

One way to estimate $\theta$ is to drop the country fixed effects and substitute them with aid as well as range of country-level variables that should affect average growth rates for industries in countries. In departing from the Rajan-Zingales methodology, we open ourselves to the standard criticism of cross-country regressions- that we may not have 
included all the country-level variables that might matter. But in return for this, we obtain a rough estimate of the average effect of aid. In Table 11, moving across the columns, we add variables that are typically considered important determinants of overall growth, including initial income per capita, trade policy, institutional quality, life expectancy, and geography. What is remarkable is that we find a robust negative effect for the aid coefficient while the coefficient of the aid-labor share interaction term remains negative and significant as in the core specification.

Taking column 6 as the most general specification, we find that a one percentage point increase in the ratio of aid-to-GDP reduces average annual manufacturing sector growth (when evaluated at the mean value of labor intensity) by 0.45 percent in the $1980 \mathrm{~s}^{26}$

\section{RELATIONSHIP TO THE LITERATURE}

We are not the first to examine the possibility that aid contributes to Dutch Disease. Yano and Nugent (1999) find mixed evidence on the relationship between aid flows, real exchange rates, and the structure of production in a set of 44 aid-dependent economies (receiving more than 5 percent annually in aid) during 1970-1990. The authors find that aid is associated with an appreciation of the real exchange rate in less than half the countries, and find the reverse in the rest. In only one or two of the countries is aid determined to be immiserizing.

By contrast, Elbadawi (1999) using panel data for 62 countries, including 28 African countries, shows that aid is positively correlated with the real exchange rate, with a 35

\footnotetext{
${ }^{26}$ We get similar results for the 1990s. In this decade, an increase of one percentage point increase in the ratio of aid-to-GDP reduces average annual manufacturing sector growth (when evaluated at the mean value of labor intensity) by 0.52 percent.
} 
percent increase in the ratio of aid to GDP correlated with a 3 percent real overvaluation. ${ }^{27}$

He also finds that aid has a deleterious impact on nontraditional exports, with the relationship being an inverted $U$ and the level of nontraditional exports being maximized at an aid-toGDP ratio of about 22 percent. Interestingly, though, his estimates would suggest that aid helps non-traditional exports for most aid receiving countries, because the significant majority of them receive aid less than the threshold number. ${ }^{28}$ Put another way, his findings cannot explain why the manufacturing sector is so small in aid-receiving countries.

Other papers are less explicit about the real exchange rate channel but focus more on outcomes. Prati and Tressel (2006), using a panel framework, demonstrate that aid has a negative effect on overall exports but only in normal times, defined as those periods that are not characterized by shocks (droughts, hurricanes, earthquakes, or plummeting commodity export prices). During normal times, which constitute about 60 percent of total country-year observations, they estimate that a 1 percentage point increase in the ratio of aid to GDP reduces the ratio of exports to GDP by 0.3-0.6 percent of GDP at impact, with a long run effect that is about 5-6 times as large.

Arellano et. al. (2004), drawing on panel data regressions for 73 aid-receiving developing countries during 1981-2000 find a strong and significant negative relationship between aid and the share of manufactured exports in total exports. They find that a one

27 This mixed relationship between aid and real exchange rates in these first two cited studies is also found more generally found in the literature. Younger (1992), Vos (1998), and AtingiEgo and Sebudde (2000) find a positive relationship for Ghana, Pakistan, and Uganda respectively, while Nyoni (1998) found aid led to a depreciated real exchange rate in Tanzania).Given the difficulty in measuring the real exchange rate, and controlling for other simultaneous events (such as liberalization), it is not surprising that country specific studies offer mixed evidence. This is probably why the evidence on relative industry performance is more compelling.

${ }^{28}$ Whether "non-traditional" exports are more likely to be affected by Dutch Disease depends, to some extent, on what the non-traditional exports are. So there is not an easy correspondence between his work and ours. 
percentage increase in the ratio of aid to GDP relative to the mean lowers manufactured

exports by 0.4 to 1 percentage points of total exports. Similarly, Bulir and Lane (2002) find that the tradable sector has shrunk dramatically in more aid dependent countries between 1985 and 1999, by about 8 percentage points of GDP.

These studies, as indeed many others, are at the cross-country level and focused on aggregate manufacturing or total production of tradable goods. Because our paper focuses on differences in growth rates between industries, our work is less subject to the criticism that an omitted country variable that is correlated with aid could explain our results. Not only would the omitted variable have to be strongly correlated with aid, but also it would have to induce a pattern of relative industry growth similar to the one observed. More important, our specification allows us to focus more directly on the Dutch Disease channel, and thus it provides a more powerful test of the phenomenon.

With notable exceptions (Prati and Tressel (2006), for example), papers in the literature do not address the issue of endogeneity carefully - that a country may be poor and receive aid because its manufacturing or tradable sectors are small rather than its manufacturing sector being small because it receives aid. Our paper goes some way in tackling this issue.

\section{CONCLUding Remarks}

Taken together, our results suggest there is indeed an adverse impact of aid on competitiveness - we provide evidence that aid inflows have systematic adverse effects on the relative growth of labor intensive and export sectors, and that the channel through which these effects are felt is the exchange rate overvaluation induced by aid. We can also assert with some confidence that aid depresses the average growth rate of the manufacturing sector in a country. Despite the fact that for many aid-receiving countries the manufacturing sector might be less important currently than agriculture, it is worth remembering that that was also 
true for many of the fast-growing countries when they first embarked upon development. Manufacturing exports provided the vehicle for their growth take-off, so any adverse effects on such exports should prima facie be a cause for concern about the effects of aid on growth. Also, taking both the relative and average growth effects of aid together, we have shown the employment generating labor-intensive sectors grow far more slowly in countries that receive more aid. This should be a source of concern for those who see aid as an instrument to reduce inequality, for labor intensive sectors are the ones that can absorb the poor and landless who leave agriculture.

Our paper suggests that in the rush to ramp up aid, we should not lose sight of issues like how much aid can be handled to begin with, how the aid should be delivered, and when. At the very least, our work suggests a poor country need not have the absorptive capacity to take in a massive quantity of aid up front without it creating substantial adverse effects on the country's export competitiveness. Far better to build up the supply of the other critical resources that will be needed to use aid effectively such as a larger body of skilled workers. Yet education and training of the unskilled, even if undertaken on a war footing, takes time. A massive expansion of the resources devoted to education can create the very adverse effects in the short term that it will hopefully avoid in the longer term. A better solution might be to start slow but to accelerate as capacity is built. Even though the world is impatient for the poor to develop, development, especially when mandated from the outside, may require patience.

Because of the ambiguities in the theory, our evidence does not suggest that the adverse effects of aid on competitiveness are inevitable, only that adverse effects have been the historical experience. From a research perspective, it is perhaps more fruitful now to move beyond the inconclusive debate of whether aid is effective, and focus on specific ways 
it can be made to work better, by better understanding the reasons that might impair or enhance its effectiveness. 
Table 1. Summary Statistics

A. Across Countries and Industries in the Base Sample

\begin{tabular}{|c|c|c|c|c|c|c|c|}
\hline \multicolumn{8}{|c|}{ A. Across Countries and Industries in the Base Sample } \\
\hline Variables & Period & \multicolumn{4}{|c|}{ Standard } & Maximum & $\begin{array}{c}\text { Number of } \\
\text { Observations }\end{array}$ \\
\hline \multirow[t]{2}{*}{ Growth Rate of Value Added ij } & $1980 \mathrm{~s}$ & 0.018 & 0.015 & 0.119 & -0.457 & 0.754 & 712 \\
\hline & $1990 \mathrm{~s}$ & 0.030 & 0.037 & 0.108 & -0.530 & 0.337 & 357 \\
\hline \multirow[t]{2}{*}{ Initial Industry Share ij } & $1980 \mathrm{~s}$ & 0.044 & 0.022 & 0.067 & 0.00005 & 0.562 & 712 \\
\hline & $1990 \mathrm{~s}$ & 0.041 & 0.020 & 0.064 & 0.00007 & 0.525 & 357 \\
\hline \multicolumn{8}{|c|}{ B. Across Industries in the Base Sample } \\
\hline Variables & Period & Mean & Median & $\begin{array}{l}\text { Standard } \\
\text { Deviation }\end{array}$ & Minimum & Maximum & $\begin{array}{c}\text { Number of } \\
\text { Observations }\end{array}$ \\
\hline \multirow[t]{2}{*}{$\overline{\text { Labor Share } i}$} & $1980 \mathrm{~s}$ & 0.403 & 0.424 & 0.084 & 0.193 & 0.515 & 28 \\
\hline & $1990 \mathrm{~s}$ & 0.358 & 0.365 & 0.088 & 0.174 & 0.515 & 28 \\
\hline Financial Dependence $i$ & 1980s, 1990s & 0.243 & 0.219 & 0.336 & -0.451 & 1.140 & 27 \\
\hline Exportability Index $i$ & $1980 \mathrm{~s}, 1990 \mathrm{~s}$ & 0.5 & 0.5 & 0.509 & 0 & 1 & 28 \\
\hline \multicolumn{8}{|c|}{ C. Across Countries in the Base Sample } \\
\hline Variables & Period & Mean & Median & $\begin{array}{l}\text { Standard } \\
\text { Deviation }\end{array}$ & Minimum & Maximum & $\begin{array}{c}\text { Number of } \\
\text { Observations }\end{array}$ \\
\hline \multirow[t]{2}{*}{$\overline{\text { Aid to } G D P j}$} & $1980 \mathrm{~s}$ & 0.058 & 0.046 & 0.042 & 0.008 & 0.176 & 33 \\
\hline & $1990 \mathrm{~s}$ & 0.050 & 0.036 & 0.042 & 0.006 & 0.139 & 15 \\
\hline \multirow[t]{2}{*}{ Real Exchange Rate Overvaluation $j$} & $1980 \mathrm{~s}$ & 1.186 & 1.074 & 0.488 & 0.406 & 2.204 & 31 \\
\hline & $1990 \mathrm{~s}$ & 0.919 & 0.951 & 0.354 & 0.426 & 1.787 & 15 \\
\hline \multirow[t]{2}{*}{ Policy (Sachs-Warner) index $j$} & $1980 \mathrm{~s}$ & 0.152 & 0.000 & 0.364 & 0.000 & 1.000 & 33 \\
\hline & $1990 \mathrm{~s}$ & 0.467 & 0.000 & 0.516 & 0.000 & 1.000 & 15 \\
\hline \multirow[t]{2}{*}{ Black Market Premium j } & $1980 \mathrm{~s}$ & 0.593 & 0.164 & 1.143 & -0.008 & 5.936 & 31 \\
\hline & $1990 \mathrm{~s}$ & 0.149 & 0.054 & 0.309 & 0.017 & 1.247 & 15 \\
\hline \multirow[t]{2}{*}{ Initial per Capita Income j (in log) } & $1980 \mathrm{~s}$ & 7.685 & 7.762 & 0.692 & 6.406 & 9.344 & 32 \\
\hline & $1990 \mathrm{~s}$ & 7.722 & 7.830 & 0.752 & 6.202 & 9.106 & 15 \\
\hline \multirow[t]{2}{*}{ Life Expectancy $j$} & $1980 \mathrm{~s}$ & 56.56 & 54.83 & 7.85 & 44.21 & 72.85 & 33 \\
\hline & $1990 \mathrm{~s}$ & 60.37 & 61.71 & 8.05 & 45.00 & 70.31 & 15 \\
\hline \multirow[t]{2}{*}{ Geography $j$} & $1980 \mathrm{~s}$ & -0.678 & -1.014 & 0.566 & -1.040 & 0.724 & 33 \\
\hline & 1990s & -0.660 & -1.014 & 0.611 & -1.040 & 0.724 & 15 \\
\hline \multirow[t]{2}{*}{ Institutional Quality $(I C R G)$ index $j$} & $1980 \mathrm{~s}$ & 0.429 & 0.430 & 0.132 & 0.183 & 0.723 & 29 \\
\hline & $1990 \mathrm{~s}$ & 0.525 & 0.522 & 0.057 & 0.405 & 0.610 & 14 \\
\hline
\end{tabular}


Table 2. Impact of Aid on Sectoral Growth: Core Specification for 1980s

\begin{tabular}{|c|c|c|c|}
\hline \multicolumn{4}{|c|}{$\begin{array}{l}\text { Panel A: Dependent variable is the annual average rate of growth of value added } \\
\text { of industry }(i) \text { in country }(j)\end{array}$} \\
\hline & OLS & $\begin{array}{c}2 \\
\text { OLS } \\
\text { (reduced } \\
\text { form) }\end{array}$ & $\begin{array}{c}3 \\
\text { IV }\end{array}$ \\
\hline Initial industry share(ij) & $\begin{array}{c}-0.026 * * * \\
{[0.005]}\end{array}$ & $\begin{array}{l}-0.027 * * * \\
{[0.005]}\end{array}$ & $\begin{array}{c}-0.026 * * * \\
{[0.005]}\end{array}$ \\
\hline Aid/GDP(j)* Labor share(i) & $\begin{array}{l}-0.012 * * \\
{[0.005]}\end{array}$ & & $\begin{array}{c}-0.035 * * \\
{[0.014]}\end{array}$ \\
\hline Fitted Aid/GDP(j)*Labor share(i) & \multicolumn{3}{|c|}{$\begin{array}{c}-0.020 * * * \\
{[0.006]}\end{array}$} \\
\hline Observations & 712 & 712 & 712 \\
\hline R-squared & 0.41 & 0.42 & 0.38 \\
\hline \multicolumn{4}{|c|}{$\begin{array}{c}\text { Panel B: First Stage for IV in Column } 3 \text { of Panel A above } \\
\text { Dependent variable is Aid/GDP }(j) * \text { Labor Share }(i)\end{array}$} \\
\hline Initial industry share(ij) & & & $\begin{array}{c}0.026 \\
{[0.049]}\end{array}$ \\
\hline Fitted Aid/GDP(j)*Labor share(i) & & & $\begin{array}{c}0.591 * * * \\
{[0.122]}\end{array}$ \\
\hline Observations & & & 712 \\
\hline R-squared & & & 0.25 \\
\hline
\end{tabular}

All standard errors, reported below the coefficient estimates, are robust. ***, **, and * denote significance at 1, 5, and 10 percent, respectively. All equations include country and industry fixed effects. All regressors are standardized so that the coefficients measure the impact of a one standard deviation increase in the $\mathrm{j}$ variable times a one standard deviation increase in the $i$ variable. Initial industry share (ij) refers to the share of industry $i$ in country $j$ as a share of total manufacturing sector value added in country $j$. Aid/GDP (j) refers to the share of aid to GDP in country $\mathrm{j}$ averaged over the period. Labor share (i) refers to the share of wages in valued added in industry $\mathrm{i}$ averaged over all countries. In column (2) of Panel A, the instrument for the endogenous variable (fitted aid) rather than the endogenous variable is included as the regressor. In column 3, the estimation uses instrumental variables (IV) methods. In Panel B, the dependent variable (which is the endogenous regressor in column 3 in Panel A) is the product of aid/GDP in country $\mathrm{j}$ times labor share (i). Fitted aid is obtained from estimating a gravity-type model of bilateral aid flows as described in Section II of the paper. 


\begin{tabular}{lcc}
\hline \multicolumn{3}{c}{ Table 3. Impact of Aid on Sectoral Growth for 1990: Robustness to Time Period } \\
\hline \multicolumn{4}{c}{ Panel A: Dependent variable is the annual average rate of growth of value added } \\
of industry $(i)$ in country $(j)$
\end{tabular}

All standard errors, reported below the coefficient estimates, are robust. ***, **, and * denote significance at 1, 5, and 10 percent, respectively. All equations include country and industry fixed effects. All regressors are standardized so that the coefficients measure the impact of a one standard deviation increase in the $\mathrm{j}$ variable times a one standard deviation increase in the $\mathrm{i}$ variable. Initial industry share (ij) refers to the share of industry $i$ in country $j$ as a share of total manufacturing sector value added in country $j$. Aid/GDP ( $j$ ) refers to the share of aid to GDP in country $\mathrm{j}$ averaged over the period. Labor share (i) refers to the share of wages in valued added in industry i averaged over all countries. In column (2) of Panel A, the instrument for the endogenous variable (fitted aid) rather than the endogenous variable is included as the regressor. In column 3, the estimation uses instrumental variables (IV) methods. In Panel B, the dependent variable (which is the endogenous regressor in column 3 in Panel A) is the product of aid/GDP in country j times labor share (i). Fitted aid is obtained from estimating a gravity-type model of bilateral aid flows as described in Section II of the paper. 
Table 4. Impact of Aid on Sectoral Growth for 1980s: Robustness to Samples

Dependent variable is annual average rate of growth of value added of industry $i$ in country $j$

\begin{tabular}{|c|c|c|c|c|}
\hline & $\begin{array}{c}1 \\
\text { Outliers } \\
\text { Excluded }\end{array}$ & $\begin{array}{c}2 \\
\text { "Winsorize" } \\
\text { sample at } \\
1 \% \text { and } 99 \% \\
\end{array}$ & $\begin{array}{c}3 \\
\text { "Winsorize" } \\
\text { sample at } \\
5 \% \text { and } 95 \% \\
\end{array}$ & $\begin{array}{c}4 \\
\text { Exclude higher } \\
\text { income countries }\end{array}$ \\
\hline Aid/GDP(j)* Labor share(i) & $\begin{array}{c}-0.032 * * \\
{[0.015]} \\
\end{array}$ & $\begin{array}{c}-0.031 * * \\
{[0.013]} \\
\end{array}$ & $\begin{array}{c}-0.023 * * \\
{[0.010]} \\
\end{array}$ & $\begin{array}{c}-0.028 * \\
{[0.014]} \\
\end{array}$ \\
\hline Observations & 683 & 712 & 712 & 658 \\
\hline R-squared & 0.42 & 0.41 & 0.43 & 0.4 \\
\hline
\end{tabular}

All columns use IV estimations. All standard errors, reported below the coefficient estimates, are robust. ***, $* *$, and $*$ denote significance at 1,5 , and 10 percent, respectively. All equations include country and industry fixed effects as well as the initial share of industry $\mathrm{i}$ in country $\mathrm{j}$. All regressors are standardized so that the coefficients measure the impact of a one standard deviation increase in the $\mathrm{j}$ variable times a one standard deviation increase in the i variable. In column (1), outliers are excluded according to the Hadi (1992) procedure. In column (2), values of all the left- and right- hand side variables that are greater (smaller) than the $99^{\text {th }}\left(1^{\text {st }}\right)$ percentile are set at the $99^{\text {th }}\left(1^{\text {st }}\right)$ percentile. This is repeated in column (3), except that the cut-off is set at the $95^{\text {th }}\left(5^{\text {th }}\right)$ percentile. In column (4), three higher income countries-Israel, Thailand, and Poland—are excluded.

Table 5. Impact of Aid on Sectoral Growth for 1980s: Other Robustness Checks Dependent variable is annual average rate of growth of value added of industry i in country $j$

\begin{tabular}{|c|c|c|c|c|c|}
\hline & $\begin{array}{c}1 \\
\text { Low labor } \\
\text { share } \\
\text { correlation } \\
\text { countries } \\
\text { excluded }\end{array}$ & $\begin{array}{c}2 \\
\text { Initial labor } \\
\text { share used }\end{array}$ & $\begin{array}{c}3 \\
\text { Alternative } \\
\text { instrument } \\
\text { for aid }\end{array}$ & $\begin{array}{c}4 \\
\text { Standard } \\
\text { errors } \\
\text { clustered } \\
\text { by industry }\end{array}$ & $\begin{array}{c}5 \\
\text { Standard } \\
\text { errors } \\
\text { clustered } \\
\text { by country }\end{array}$ \\
\hline Aid/GDP(j)* Labor share(i) & $\begin{array}{c}-0.031 * * \\
{[0.013]}\end{array}$ & $\begin{array}{c}-0.026 * * \\
{[0.013]}\end{array}$ & $\begin{array}{c}-0.035 * * \\
{[0.015]}\end{array}$ & $\begin{array}{c}-0.035^{* *} \\
{[0.016]}\end{array}$ & $\begin{array}{c}-0.035 * * \\
{[0.017]}\end{array}$ \\
\hline Observations & 636 & 712 & 712 & 712 & 712 \\
\hline R-squared & 0.41 & 0.39 & 0.38 & 0.38 & 0.38 \\
\hline
\end{tabular}

All columns use IV estimations. All standard errors, reported below the coefficient estimates, are robust. ***, $* *$, and $*$ denote significance at 1,5 , and 10 percent, respectively. All equations include country and industry fixed effects as well as the initial share of industry $\mathrm{i}$ in country $\mathrm{j}$. All regressors are standardized so that the coefficients measure the impact of a one standard deviation increase in the $\mathrm{j}$ variable times a one standard deviation increase in the i variable. In column (1), countries whose labor share parameters are not significantly correlated with the average labor share parameter for the whole sample are excluded. In column (2), the initial value of the labor share rather than the average during the time period is used. In column (3), a different instrument is used for aid which is described in the text. In columns (4) and (5), standard errors are clustered, respectively, by industry and country. 
Table 6. Impact of Aid on Sectoral Growth for 1980s: Robustness to Measures of Aid Dependent variable is annual average rate of growth of value added of industry $i$ in country $j$

\begin{tabular}{lcccc}
\hline & 1 & 2 & 3 & 4 \\
& $\begin{array}{c}\text { Aid excludes } \\
\text { technical } \\
\text { assistance }\end{array}$ & $\begin{array}{c}\text { Aid is } \\
\text { technical } \\
\text { assistance }\end{array}$ & $\begin{array}{c}\text { Aid is } \\
\text { early impact } \\
\text { aid }\end{array}$ & $\begin{array}{c}\text { Aid is } \\
\text { late impact } \\
\text { aid }\end{array}$ \\
\hline Aid/GDP(j)* Labor share(i & $-0.041^{*}$ & $-0.026 * *$ & $-0.069 * *$ & $-0.041^{* * *}$ \\
& {$[0.019]$} & {$[0.008]$} & {$[0.035]$} & {$[0.014]$} \\
\hline Observations & 712 & 712 & 712 & 712 \\
R-squared & 0.35 & 0.42 & 0.21 & 0.38 \\
\hline
\end{tabular}

All columns use IV estimations. All standard errors, reported below the coefficient estimates, are robust. ***, $* *$, and $*$ denote significance at 1,5 , and 10 percent, respectively. All equations include country and industry fixed effects as well as the initial share of industry $\mathrm{i}$ in country j. All regressors are standardized so that the coefficients measure the impact of a one standard deviation increase in the $j$ variable times a one standard deviation increase in the i variable. Early and late-impact aid are from Clemens et. al. (2004).

Table 7. Impact of Aid on Sectoral Growth for 1980s: Robustness to Quantity-Based Outcome Variable Dependent variable is Dependent variable is average of annual rate of growth average of annual rate of growth of employment of industry $i$ in of the index of industrial production

\begin{tabular}{lcc} 
& $\begin{array}{c}\text { of employment of industry } i \text { in } \\
\text { country } j\end{array}$ & $\begin{array}{c}\text { of the index of industrial production } \\
\text { of industry } i \text { in country } j\end{array}$ \\
\hline Aid/GDP(j)* Labor share(i) & 1 & 2 \\
& $-0.021 * * *$ & $-0.012 * * *$ \\
Observations & {$[0.008]$} & {$[0.004]$} \\
R-squared & 633 & 576 \\
\hline
\end{tabular}

All columns use IV estimations. All standard errors, reported below the coefficient estimates, are robust. ***, **, and * denote significance at 1,5 , and 10 percent, respectively. All equations include country and industry fixed effects; column 1 includes the initial share of employment and column 2 the initial share of industry i in country $\mathrm{j}$. Note that the decrease in sample size, relative to the core specification is because data on employment and industrial production are available for fewer countries and/or industries. 
Table 8. Impact of Aid on Sectoral Growth for 1980s: Robustness to Alternative Measure of Tradability Dependent variable is annual average rate of growth of value added of industry $i$ in country $j$

\begin{tabular}{|c|c|c|c|}
\hline & $\begin{array}{c}1 \\
\text { OLS }\end{array}$ & $\begin{array}{c}2 \\
\text { OLS } \\
\text { reduced } \\
\text { form }\end{array}$ & $\begin{array}{c}3 \\
\text { IV }\end{array}$ \\
\hline Initial industry share(ij) & $\begin{array}{c}-0.024 * * * \\
{[0.005]}\end{array}$ & $\begin{array}{c}-0.024 * * * \\
{[0.005]}\end{array}$ & $\begin{array}{c}-0.022 * * * \\
{[0.006]}\end{array}$ \\
\hline Aid/GDP(j)*Exportability index(i) & $\begin{array}{c}-0.021 * * \\
{[0.009]}\end{array}$ & & $\begin{array}{c}-0.052 * * \\
{[0.023]}\end{array}$ \\
\hline Fitted Aid/GDP $(j) *$ Exportability index(i) & & $\begin{array}{c}-0.027 * * \\
{[0.011]}\end{array}$ & \\
\hline $\begin{array}{l}\text { Observations } \\
\text { R-squared }\end{array}$ & $\begin{array}{l}712 \\
0.41\end{array}$ & $\begin{array}{r}712 \\
0.41\end{array}$ & $\begin{array}{l}712 \\
0.4\end{array}$ \\
\hline \multicolumn{4}{|c|}{$\begin{array}{l}\text { Panel B: First Stage for IV in Column } 3 \text { of Panel A above } \\
\text { Dependent variable is Aid/GDP }(j)^{*} \text { Exportability index }(i)\end{array}$} \\
\hline Initial industry share(ij) & & & $\begin{array}{c}0.038 \\
{[0.028]}\end{array}$ \\
\hline Fitted Aid/GDP(j)*Exportability index(i) & & & $\begin{array}{c}0.513 * * * \\
{[0.074]}\end{array}$ \\
\hline Observations & & & 712 \\
\hline R-squared & & & 0.6 \\
\hline
\end{tabular}

All standard errors, reported below the coefficient estimates, are robust. $* * *, * *$, and $*$ denote significance at 1,5 , and 10 percent, respectively. All equations include country and industry fixed effects. All regressors are standardized so that the coefficients measure the impact of a one standard deviation increase in the $j$ variable times a one standard deviation increase in the $\mathrm{i}$ variable. Initial industry share (ij) refers to the share of industry $i$ in country $j$ as a share of total manufacturing sector value added in country $j$. Aid/GDP (j) refers to the share of aid to GDP in country $\mathrm{j}$ averaged over the period. Exportability (i) is a dummy that takes a value of 1 if industry $i$ has a ratio of exports to value that exceeds the industry median value. For each industry, the ratio of exports to value added was averaged over the set of developing countries in our core sample for which data were available. In column (2) of Panel A, the instrument for the endogenous variable (fitted aid) rather than the endogenous variable is included as the regressor. In column 3, the estimation uses instrumental variables (IV) methods. In Panel B, the dependent variable (which is the endogenous regressor in column 3 in Panel A) is the product of aid/GDP in country $\mathrm{j}$ times exportability index (i). Fitted aid is obtained from estimating a gravitytype model of bilateral aid flows as described in Section II of the paper. 


\begin{tabular}{|c|c|c|c|c|c|c|}
\hline \multicolumn{7}{|c|}{$\begin{array}{c}\text { Table 9A. Impact of Real Exchange Rate Overvaluation on Sectoral Growth for 1980s } \\
\text { Dependent variable is annual average rate of growth of value added of industry } i \text { in country } j\end{array}$} \\
\hline & 1 & 2 & 3 & 4 & 5 & 6 \\
\hline & OLS & OLS & IV & OLS & OLS & IV \\
\hline & \multicolumn{3}{|c|}{ reduced form } & \multicolumn{3}{|c|}{ reduced form } \\
\hline Initial industry share(ij) & $-0.027 * * *$ & $-0.027 * * *$ & $-0.027 * * *$ & $-0.026 * * *$ & $-0.025^{* * *}$ & $-0.025 * * *$ \\
\hline & {$[0.005]$} & {$[0.005]$} & {$[0.006]$} & {$[0.006]$} & {$[0.006]$} & {$[0.006]$} \\
\hline Overvaluation(j)* Labor share(i) & $-0.020 * * *$ & & $-0.073 * * *$ & & & \\
\hline & {$[0.004]$} & & {$[0.025]$} & & & \\
\hline Fitted Aid/GDP(j)* Labor share(i) & & $-0.024 * * *$ & & & & \\
\hline & & {$[0.007]$} & & & & \\
\hline \multirow[t]{2}{*}{ Overvaluation(j)*Exportability index(i) } & & & & $-0.013 *$ & & $-0.080 *$ \\
\hline & & & & [0.007] & & {$[0.048]$} \\
\hline \multirow[t]{2}{*}{ Fitted Aid/GDP(j)*Exportability index(i) } & & & & & $-0.021 *$ & \\
\hline & & & & & {$[0.013]$} & \\
\hline Observations & 674 & 674 & 674 & 674 & 674 & 674 \\
\hline R-squared & 0.44 & 0.42 & 0.24 & 0.41 & 0.41 & 0.33 \\
\hline
\end{tabular}

All standard errors, reported below the coefficient estimates, are robust. ***, **, and $*$ denote significance at 1, 5, and 10 percent, respectively. All equations include country and industry fixed effects. All regressors are standardized so that the coefficients measure the impact of a one standard deviation increase in the $\mathrm{j}$ variable times a one standard deviation increase in the $\mathrm{i}$ variable. The overvaluation variable is from Easterly and Levine (2003). In columns 2 and 5, the instrument for the endogenous variable (fitted aid) rather than the endogenous variable is included as the regressor. In columns 3 and 6, the estimation uses instrumental variables (IV) methods. Fitted aid is obtained from estimating a gravity-type model of bilateral aid flows as described in Section II of the paper. Note that the sample size is smaller than in the core specification because data on overvaluation are available for two fewer countries.

\section{Table 9B. Impact of Exogenous Determinants of Aid on Overvaluation for $1980 \mathrm{~s}$}

1

Dependent variable is

Overvaluation(j)*

Labor share(i)

$0.322 * * *$

[0.095]
2

Dependent variable is

Overvaluation $(\mathrm{j}) *$

Exportability Index(i)

Fitted Aid/GDP(j)* Labor share(i)

$0.263 * * *$

Fitted Aid/GDP(j)*Exportability Index(i)

[0.060]

Observations

674

674

R-squared

0.05

0.5

All standard errors, reported below the coefficient estimates, are robust. ***, **, and * denote significance at 1, 5, and 10 percent, respectively. These equations are the first stage corresponding respectively to the IV estimations in columns 3 and 6 of Table 9. They include country and industry fixed effects as well as the initial share of industry $\mathrm{i}$ in country $\mathrm{j}$. All regressors are standardized so that the coefficients measure the impact of a one standard deviation increase in the $\mathrm{j}$ variable times a one standard deviation increase in the $\mathrm{i}$ variable. In column 1, the dependent variable is the product of aid/GDP in country j and labor share (i) and in column 2 the product of aid/GDP and the exportability index. Fitted aid is obtained from estimating a gravity-type model of bilateral aid flows as described in Section II of the text. Note that the sample size is smaller than in the core specification because data on overvaluation are available for two fewer countries. 


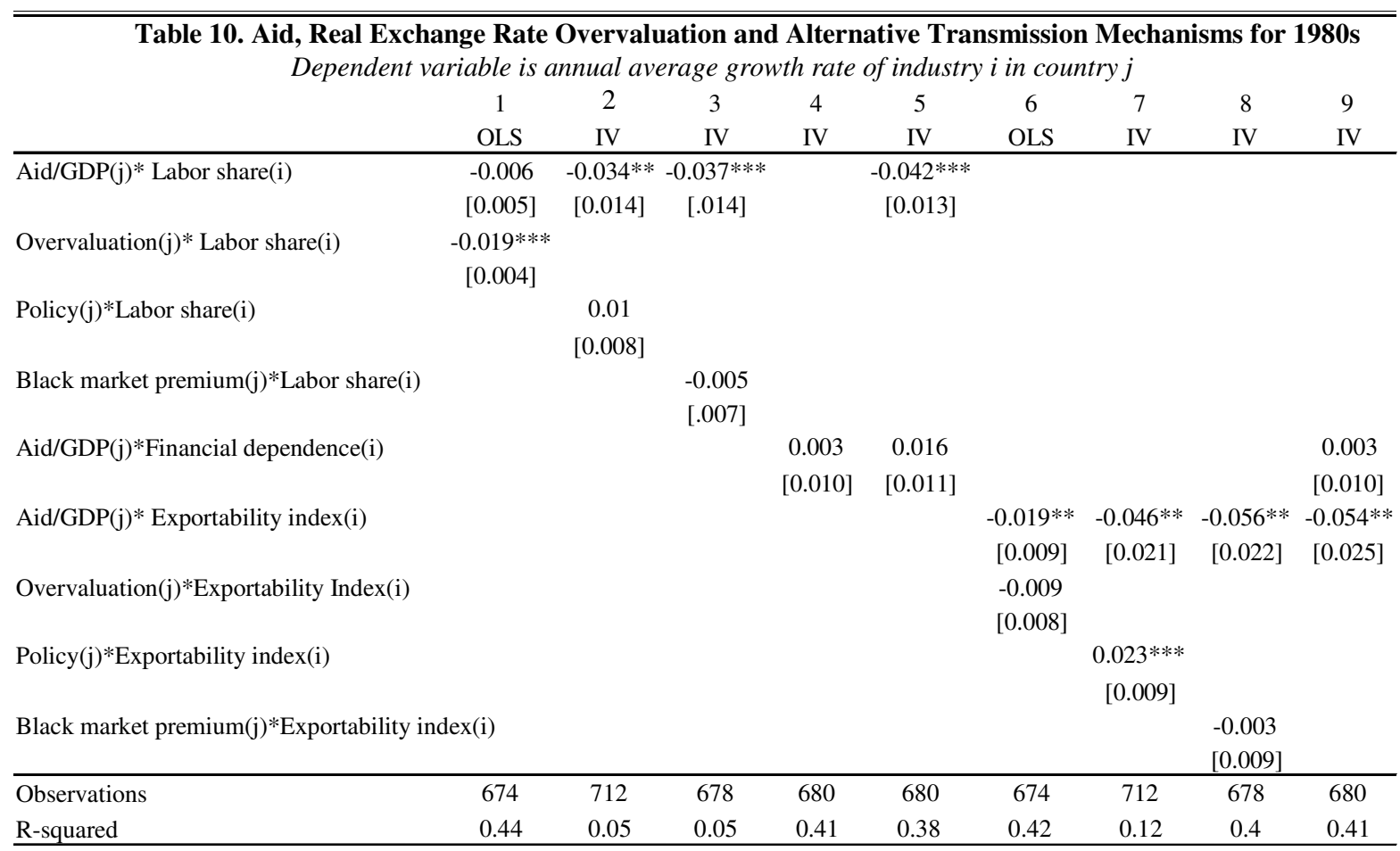

All standard errors, reported below the coefficient estimates, are robust. ***, **, and * denote significance at 1 , 5, and 10 percent, respectively. All equations include country and industry fixed effects as well as the initial share of industry $\mathrm{i}$ in country $\mathrm{j}$. All regressors are standardized so that the coefficients measure the impact of a one standard deviation increase in the $\mathrm{j}$ variable times a one standard deviation increase in the $\mathrm{i}$ variable. The overvaluation variable is from Easterly and Levine (2003), the policy variable from Wacziarg and Welch (2003), the black market premium from Reinhart and Rogoff (2004), and the financial dependence variable from Rajan and Zingales (1998) (see Appendix Table 1A for details). In columns 5 and 9, both the aid interactions are instrumented. Note that the sample varies from the core because data on overvaluation and the black market premium are available for two fewer countries than the core sample, and data on financial dependence from Rajan and Zingales (1998) is available for one less industry. Note also that the sample varies between columns 1 and 3, and 6 and 8, because although data on overvaluation and the black market premium are missing for two countries (relative to the core), they are missing for different countries. 
Table 11. Effect of Aid on Sectoral Growth for 1980s: Absolute and Relative Effects

Dependent variable is annual average rate of growth of value added of industry $i$ in country $j$

\begin{tabular}{|c|c|c|c|c|c|c|}
\hline & 1 & 2 & 3 & 4 & 5 & 6 \\
\hline Initial industry share(ij) & $\begin{array}{c}-0.025 * * * \\
{[0.005]}\end{array}$ & $\begin{array}{c}-0.024 * * * \\
{[0.005]}\end{array}$ & $\begin{array}{c}-0.025 * * * \\
{[0.005]}\end{array}$ & $\begin{array}{c}-0.029 * * * \\
{[0.006]}\end{array}$ & $\begin{array}{c}-0.029 * * * \\
{[0.006]}\end{array}$ & $\begin{array}{c}-0.029 * * * \\
{[0.006]}\end{array}$ \\
\hline $\operatorname{Aid} / \operatorname{GDP}(\mathrm{j}) *$ Labor share(i) & $\begin{array}{c}-0.032 * * \\
{[0.013]}\end{array}$ & $\begin{array}{c}-0.028 * * * \\
{[0.010]}\end{array}$ & $\begin{array}{c}-0.028 * * * \\
{[0.010]}\end{array}$ & $\begin{array}{c}-0.027 * * * \\
{[0.009]}\end{array}$ & $\begin{array}{c}-0.027 * * * \\
{[0.009]}\end{array}$ & $\begin{array}{c}-0.026 * * * \\
{[0.009]}\end{array}$ \\
\hline $\mathrm{Aid} / \mathrm{GDP}(\mathrm{j})$ & $\begin{array}{c}-0.019 \\
{[0.013]}\end{array}$ & $\begin{array}{c}-0.020 * * \\
{[0.008]}\end{array}$ & $\begin{array}{c}-0.021 * * * \\
{[0.008]}\end{array}$ & $\begin{array}{c}-0.025 * * * \\
{[0.008]}\end{array}$ & $\begin{array}{c}-0.022 * * * \\
{[0.008]}\end{array}$ & $\begin{array}{c}-0.018 * * \\
{[0.009]}\end{array}$ \\
\hline Initial per capita GDP(j) & & $\begin{array}{c}0.013 * * \\
{[0.005]}\end{array}$ & $\begin{array}{c}0.006 \\
{[0.005]}\end{array}$ & $\begin{array}{c}0.006 \\
{[0.005]}\end{array}$ & $\begin{array}{c}0 \\
{[0.008]}\end{array}$ & $\begin{array}{c}0 \\
{[0.008]}\end{array}$ \\
\hline Policy(j) (Sachs-Warner index) & & & $\begin{array}{c}0.026 * * * \\
{[0.005]}\end{array}$ & $\begin{array}{c}0.027 * * * * \\
{[0.006]}\end{array}$ & $\begin{array}{c}0.027 * * * \\
{[0.006]}\end{array}$ & $\begin{array}{c}0.026 * * * \\
{[0.006]}\end{array}$ \\
\hline Institutional quality(j) (ICRGE) & & & & $\begin{array}{c}0.003 \\
{[0.005]}\end{array}$ & $\begin{array}{c}0.002 \\
{[0.005]}\end{array}$ & $\begin{array}{c}0.001 \\
{[0.005]}\end{array}$ \\
\hline Life expectancy(j) & & & & & $\begin{array}{c}0.008 \\
{[0.006]}\end{array}$ & $\begin{array}{c}0.007 \\
{[0.007]}\end{array}$ \\
\hline Geography(j) & & & & & & $\begin{array}{c}0.016 * * * \\
{[0.006]}\end{array}$ \\
\hline Observations & 712 & 702 & 702 & 650 & 650 & 650 \\
\hline R-squared & 0.09 & 0.11 & 0.16 & 0.15 & 0.16 & 0.17 \\
\hline
\end{tabular}

The estimations in this Table are based on instrumenting for both the aid variables, using the instruments described in Section II of the text. All standard errors, reported below the coefficient estimates, are robust. ***, **, and * denote significance at 1,5 , and 10 percent, respectively. All equations include industry but not country fixed effects. All regressors are standardized so that the coefficients measure the impact of a one standard deviation increase in the $\mathrm{j}$ variable times a one standard deviation increase in the $\mathrm{i}$ variable. Initial industry share (ij) refers to the share of industry $i$ in country $j$ as a share of total manufacturing sector value added in country j. For details on the measures for policy, life expectancy, and geography, see Appendix Table $1 \mathrm{~A}$. 
Chart 1: Manufacturing and Aid between 1980 and 2000

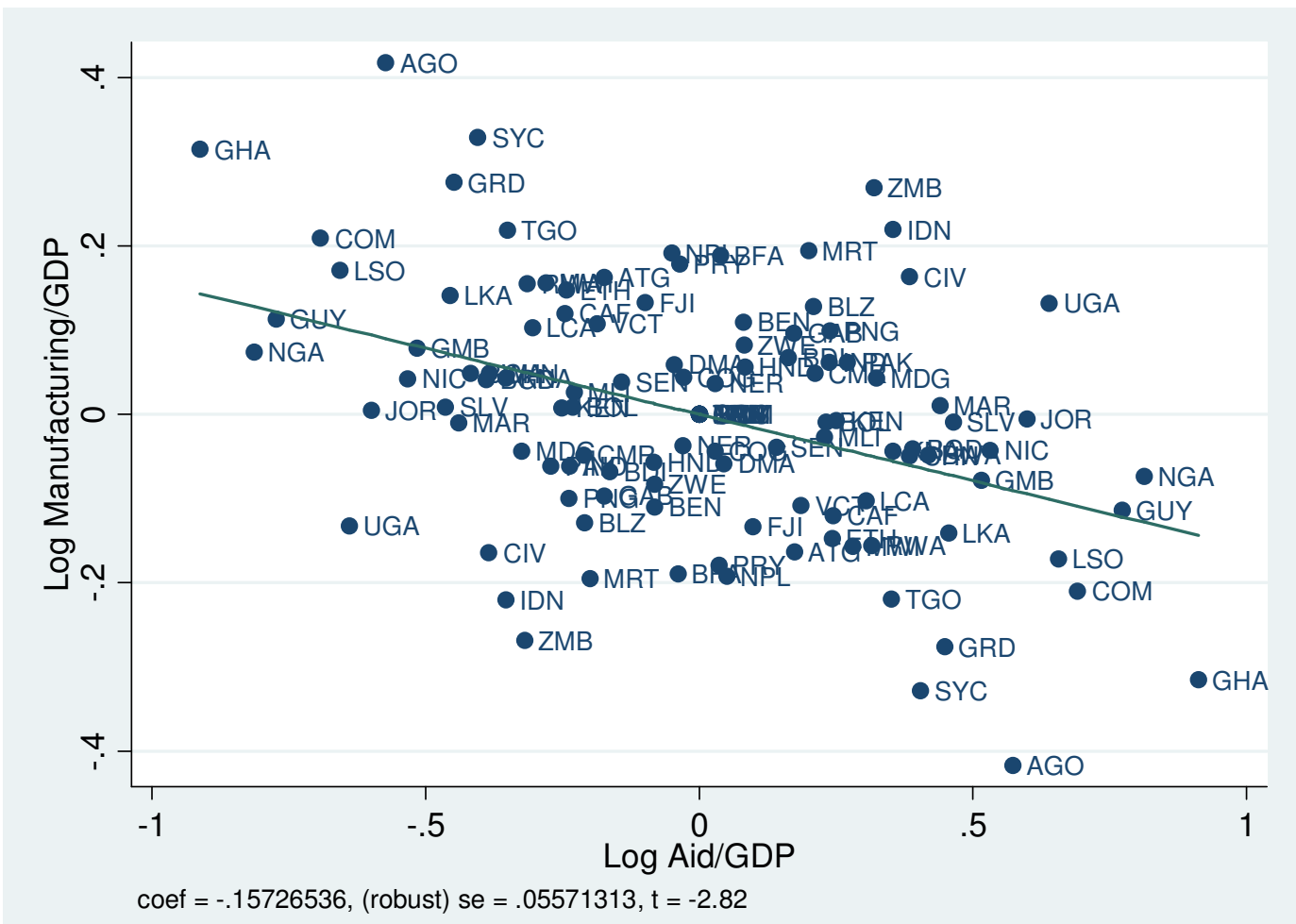

This plot represents the conditional relationship between the change in the size of the manufacturing sector between 1980 and 2000 in a country and the change in aid over the same period. It is based on running a panel regression where the dependent variable is log of the ratio of the share of value added in manufacturing to GDP for a country (at two dates, the late 1990s and the early 1980s), and the explanatory variables are the country's per capita PPP GDP, per capita PPP GDP squared, and fixed effects for the country and the time period. All variables are averages for the period 1980-85 and 1995-2000, respectively. To facilitate comparability with the core results in the paper, the sample was chosen according to the same criteria as in the core the sample of the paper, namely to include countries that had an aid-toGDP ratio greater than 1 percent or are low-income countries. Data on manufacturing are from the World Bank's World Development Indicators. 
Chart 2: Share of Manufacturing Relative to Services and Aid Between 1980 and 2000

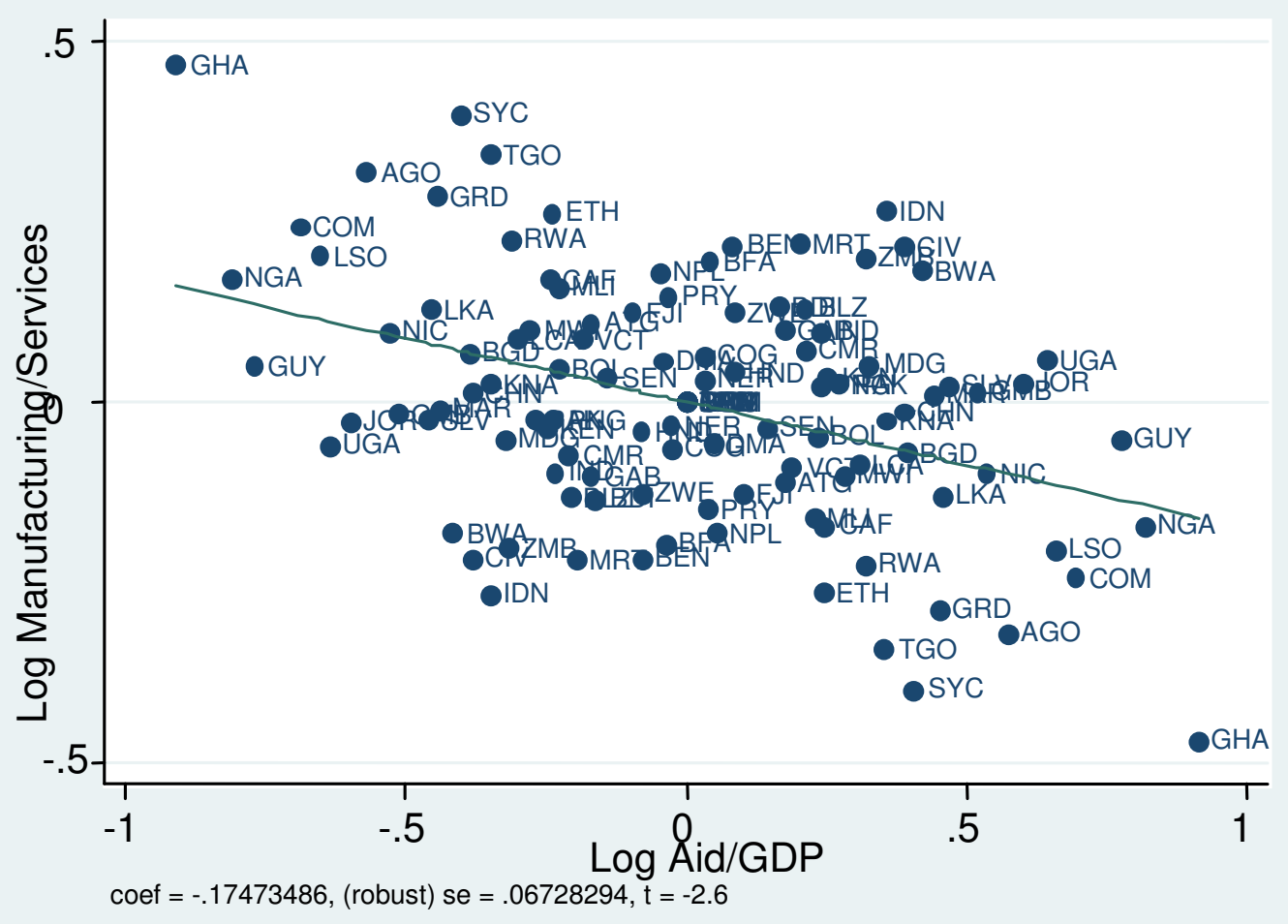

This plot represents the conditional relationship between the change in the size of the manufacturing sector relative to the size of the services sector between 1980 and 2000 in a country and the change in aid over the same period. The share of the services sector is obtained as 1-(share of agriculture + share of industry). It is based on running a panel regression where the dependent variable is log of the ratio of the share of value added in manufacturing to GDP for a country (at two dates, the late 1990s and the early 1980s), and the explanatory variables are the country's per capita PPP GDP, per capita PPP GDP squared, and fixed effects for the country and the time period. All variables are averages for the period 1980-85 and 1995-2000, respectively. To facilitate comparability with the core results in the paper, the sample was chosen according to the same criteria as in the core the sample of the paper, namely, to include countries that had an aid-to-GDP ratio greater than 1 percent or are low-income countries. Data on manufacturing and services are from the World Bank's World Development Indicators. 


\section{Chart 3: Non-Parametric Depiction of Core Result}

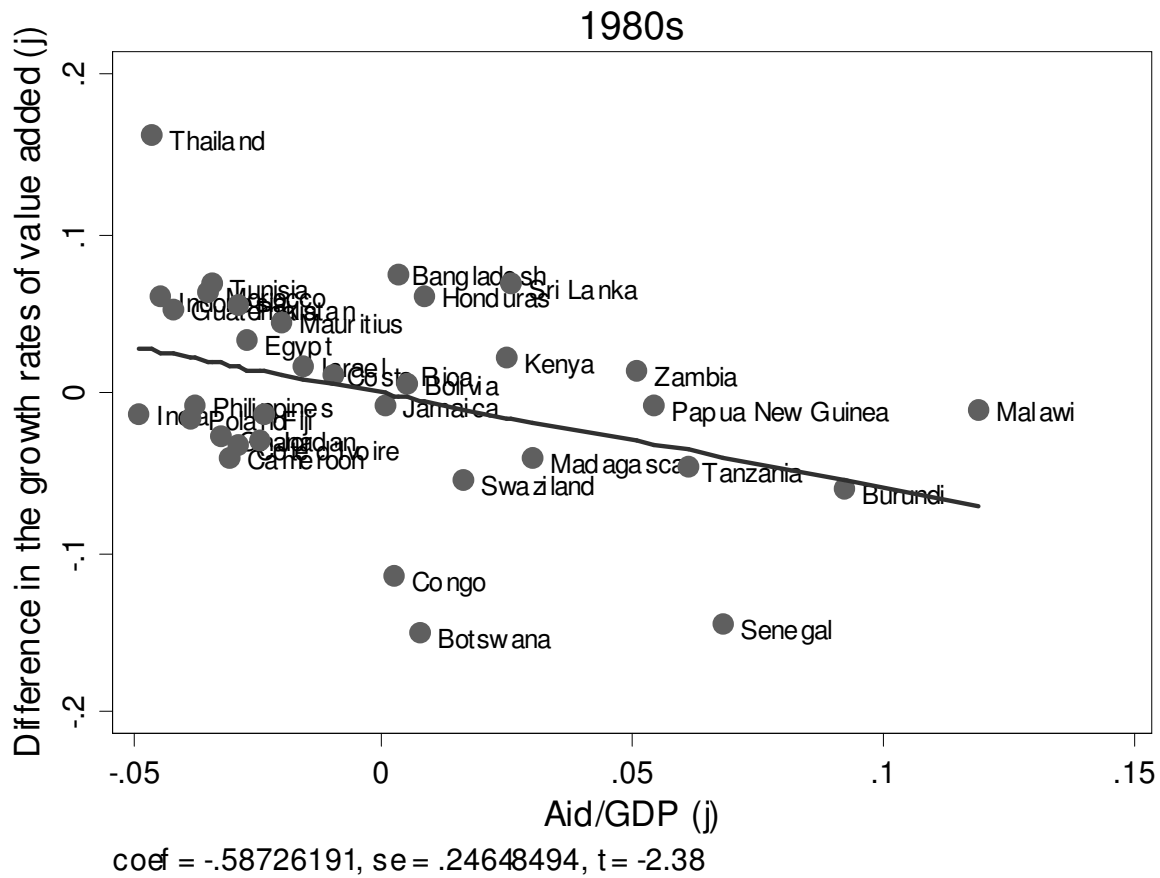

We divide the industries into two groups (above and below median) depending on their labor share. Next we estimate for each country the difference in average growth in annual value added between above and below median industries. The y-axis measures this difference, which is plotted against the aid-to-GDP received by each country (x-axis). 


\section{Appendix 1. Main Data Sources and Description}

- Industrial Statistics Database (2003) of the United Nations Industrial Development Organization (UNIDO) for data on value added and labor share. Data are at 3-digit level of the International Standard Industrial Classification of All Economic Activities (ISIC, Revision 2). [UNIDO database].

- World Development Indicators (World Bank) for the data on the share of manufacturing and services in GDP.

- WITS (World Integrated Trade Solution) data (World Bank) for exportability index.

- OECD's Development Assistance Committee (DAC) for data on aid.

\section{Growth Rate of Real Value Added:}

The UNIDO dataset provides nominal value added both in terms of US dollars and local currency. The value added figure in US dollars is used for all regression analysis. The nominal value added (in current US dollars) was changed to a real value added (in constant Year 2000 US dollars), using the U.S. Producer Production Index provided by the International Monetary Fund's International Financial Statistics (IFS). This measure was, in turn, compared with the real value added in local currency to ascertain its reliability. ${ }^{29}$ More specifically, we required the correlation between the two be higher than 0.75 to be included in our base sample.

We then calculated the average annual growth rate of real value added for industry $i$ in country $j$, for the 1980s and 1990s. We calculated this wherever data existed for at least a seven-year period.

\section{Average Labor Share:}

For each decade, the average labor share for industry $i$ was computed by taking the unweighted average of the labor share across developing (non-OECD) countries and across years for which the data on the growth rate of real value added and initial industry share was

${ }^{29}$ Since local PPI was not available for all developing countries in IFS, alternative deflators needed to be used to construct the measure of real value added in local currency.

Accordingly, whenever PPI was not available, we used the effective deflator constructed with the index of industrial production as in Rajan and Zingales (1998). This deflator is the ratio of the growth rate of nominal value added in the entire manufacturing sector (from the UNIDO database) to the growth rate of the index of industrial production (from IFS). Alternatively, a GDP deflator was used whenever these two series were not available. 
available in the UNIDO database. ${ }^{30}$ Here, the labor share refers to the ratio of "wages and salaries' to 'value added'.

Countries with aid less than $1 \%$ of GDP are not included in the regression analysis because they included a number of emerging market and other countries such as Malta, Cyprus, and Kuwait that cannot be considered meaningful aid recipients. Peru is dropped from the base sample due to its unusually high level of growth rates in all industries in the UNIDO database (i.e. exceeds $100 \%$ in all sectors). Niger is dropped from the 1990s sample as the data contained an observation where the ratio of wages to value added exceeded 17 . We also dropped observations when this ratio exceeded one (this resulted in 10 and 12 observations being dropped respectively from the sample for the 1980s and 1990s). In addition, the following countries' labor share parameters are not significantly correlated with the average labor share parameter: Bolivia, Egypt, Jordan, Mauritius and Zambia for the 1980s, and Egypt, Ethiopia, and Syrian Arab Republic for the 1990s.

${ }^{30} 954$ observations for forty countries are used for the 1980s, and 642 observations for twenty eight countries are used for the 1990s. 
Appendix Table 1A. List of Variables and Data Source

\begin{tabular}{|c|c|c|}
\hline Variable Names & Description & Source \\
\hline $\begin{array}{l}\text { Growth Rate of Value } \\
\text { Added }_{i j}\end{array}$ & $\begin{array}{l}\text { Industry } i \text { 's annual growth rate of value added in } \\
\text { country } j \text {, averaged over each decade. }\end{array}$ & UNIDO (2003). \\
\hline $\begin{array}{l}\text { Initial Industry } \\
\text { Share }_{i j}\end{array}$ & $\begin{array}{l}\text { Industry } i \text { 's share in country } j \text { 's total manufacturing } \\
\text { value added at the beginning of the decade. }\end{array}$ & UNIDO (2003). \\
\hline Labor Share $_{i}$ & $\begin{array}{l}\text { The labor share index for industry } i \text {, measured in terms } \\
\text { of the ratio of wage to value added. The industry index } \\
\text { was constructed by taking the average across years and } \\
\text { countries for each industry and decade. }\end{array}$ & UNIDO (2003). \\
\hline $\begin{array}{l}\text { Financial } \\
\text { Dependence }_{i}\end{array}$ & $\begin{array}{l}\text { The measure of external financial dependence for all } \\
\text { firms in industry } i \text { during the } 1980 \mathrm{~s} \text {. }\end{array}$ & $\begin{array}{l}\text { Rajan and Zingales } \\
\text { (1998). }\end{array}$ \\
\hline Overvaluation $j$ & $\begin{array}{l}\text { The degree of a country's real exchange rate } \\
\text { overvaluation. See Footnote xx in text for description. }\end{array}$ & $\begin{array}{l}\text { Easterly and levine } \\
(2003) \text {. }\end{array}$ \\
\hline Exportability index $_{i}$ & $\begin{array}{l}\text { A dummy that takes a value of } 1 \text { if industry } i \text { has a ratio } \\
\text { of exports to value that exceeds the industry median } \\
\text { value. For each industry, the average ratio of exports to } \\
\text { value added was calculated using a group of developing } \\
\text { countries. }\end{array}$ & $\begin{array}{l}\text { WITS data, World } \\
\text { Bank (at the 3-digit } \\
\text { ISIC code). }{ }^{31}\end{array}$ \\
\hline$\overline{A i d} / G D P_{j}$ & The ratio of aid to GDP for country $j$. & OECD DAC database. \\
\hline Policy $_{j}$ & Percent of years that a country is considered open. & $\begin{array}{l}\text { Wacziarg and Welch } \\
\text { (2003). }\end{array}$ \\
\hline $\begin{array}{l}\text { Black market } \\
\text { premium }_{j}\end{array}$ & $\begin{array}{l}\text { Percent difference between a country's parallel market } \\
\text { and official exchange rate expressed in terms of the } \\
\text { latter. }\end{array}$ & $\begin{array}{l}\text { Reinhart and Rogoff } \\
\text { (2004). }\end{array}$ \\
\hline Institutional quality $_{j}$ & $\begin{array}{l}\text { Several ICRGE indices averaged for the period 1986- } \\
1995 .\end{array}$ & $\begin{array}{l}\text { Bosworth and Collins } \\
\text { (2003). }\end{array}$ \\
\hline Life expectancy & $\begin{array}{l}\text { Life expectancy at birth for beginning of the relevant } \\
\text { decade. }\end{array}$ & WDI \\
\hline Geography $_{j}$ & Average of number of frost days and tropical land area. & $\begin{array}{l}\text { Bosworth and Collins } \\
\text { (2003). }\end{array}$ \\
\hline
\end{tabular}

${ }^{31}$ The Trade and Production Database provides the WITS trade data at the 3-digit ISIC code. This database is available at: www.worldbank.org/research/trade 


\begin{tabular}{|c|c|c|c|}
\hline \multicolumn{4}{|c|}{ Appendix Table 1B. Aid as a Percentage of GDP } \\
\hline $1980 \mathrm{~s}$ & & $1990 \mathrm{~s}$ & \\
\hline Malawi & $17.56 \%$ & Tanzania & $13.92 \%$ \\
\hline Burundi & $14.90 \%$ & Ethiopia & $10.83 \%$ \\
\hline Senegal & $12.41 \%$ & Senegal & $10.40 \%$ \\
\hline Tanzania & $11.71 \%$ & Bolivia & $7.88 \%$ \\
\hline Papua New Guinea & $11.09 \%$ & Kenya & $6.73 \%$ \\
\hline Zambia & $10.72 \%$ & Jordan & $6.32 \%$ \\
\hline Madagascar & $8.67 \%$ & Cameroon & $4.65 \%$ \\
\hline Sri Lanka & $8.20 \%$ & Sri Lanka & $3.57 \%$ \\
\hline Kenya & $8.13 \%$ & Egypt & $3.29 \%$ \\
\hline Swaziland & $7.24 \%$ & Morocco & $1.55 \%$ \\
\hline Honduras & $6.48 \%$ & Philippines & $1.37 \%$ \\
\hline Botswana & $6.37 \%$ & Tunisia & $1.32 \%$ \\
\hline Bolivia & $6.15 \%$ & Mauritius & $1.13 \%$ \\
\hline Bangladesh & $5.91 \%$ & Indonesia & $1.02 \%$ \\
\hline Congo & $5.87 \%$ & Costa Rica & $0.94 \%$ \\
\hline Jamaica & $5.68 \%$ & Panama & $0.81 \%$ \\
\hline Costa Rica & $4.61 \%$ & Algeria & $0.64 \%$ \\
\hline Israel & $4.03 \%$ & India & $0.56 \%$ \\
\hline Mauritius & $3.59 \%$ & Russia & $0.46 \%$ \\
\hline Fiji & $3.30 \%$ & Cyprus & $0.34 \%$ \\
\hline Jordan & $3.15 \%$ & Uruguay & $0.29 \%$ \\
\hline Egypt & $2.96 \%$ & Malaysia & $0.28 \%$ \\
\hline Cote d'Ivoire & $2.77 \%$ & South Africa & $0.27 \%$ \\
\hline Pakistan & $2.75 \%$ & Chile & $0.25 \%$ \\
\hline Cameroon & $2.59 \%$ & Colombia & $0.24 \%$ \\
\hline Ghana & $2.38 \%$ & Oman & $0.18 \%$ \\
\hline Tunisia & $2.25 \%$ & Venezuela & $0.05 \%$ \\
\hline Morocco & $2.14 \%$ & Korea & $0.04 \%$ \\
\hline Philippines & $1.86 \%$ & Singapore & $0.03 \%$ \\
\hline Guatemala & $1.48 \%$ & Kuwait & $0.02 \%$ \\
\hline Indonesia & $1.17 \%$ & China (Hong Kong) & $0.02 \%$ \\
\hline Thailand & $1.01 \%$ & & \\
\hline Malta & $0.99 \%$ & & \\
\hline Panama & $0.99 \%$ & & \\
\hline Cyprus & $0.92 \%$ & & \\
\hline India & $0.76 \%$ & & \\
\hline Barbados & $0.73 \%$ & & \\
\hline Uruguay & $0.37 \%$ & & \\
\hline Algeria & $0.33 \%$ & & \\
\hline Chile & $0.32 \%$ & & \\
\hline Colombia & $0.30 \%$ & & \\
\hline Bahamas & $0.19 \%$ & & \\
\hline Singapore & $0.16 \%$ & & \\
\hline Korea & $0.08 \%$ & & \\
\hline Venezuela & $0.07 \%$ & & \\
\hline Iran & $0.06 \%$ & & \\
\hline Kuwait & $0.03 \%$ & & \\
\hline
\end{tabular}


Appendix Table 1C. Description of ISIC 3-digit Industries, 1980s

\begin{tabular}{|c|c|c|c|}
\hline $\begin{array}{l}\text { ISIC } \\
\text { code }\end{array}$ & Industrial sectors & $\begin{array}{r}\text { Average } \\
\text { Labor } \\
\text { Share }\end{array}$ & $\begin{array}{r}\text { Exportability } \\
\text { Index }\end{array}$ \\
\hline 311 & Food products & 0.36 & 1 \\
\hline 313 & Beverages & 0.26 & 0 \\
\hline 314 & Tobacco & 0.24 & 0 \\
\hline 321 & Textiles & 0.47 & 1 \\
\hline 322 & Wearing apparel, except footwear & 0.51 & 1 \\
\hline 323 & Leather products & 0.45 & 1 \\
\hline 324 & Footwear, except rubber or plastic & 0.49 & 1 \\
\hline 331 & Wood products, except furniture & 0.47 & 1 \\
\hline 332 & Furniture, except metal & 0.50 & 0 \\
\hline 341 & Paper and paper products & 0.39 & 0 \\
\hline 342 & Printing and publishing & 0.51 & 0 \\
\hline 351 & Industrial chemicals & 0.35 & 1 \\
\hline 352 & Other chemicals & 0.36 & 0 \\
\hline 353 & Petroleum refineries & 0.19 & 1 \\
\hline 354 & Misc. petroleum and coal products & 0.30 & 1 \\
\hline 355 & Rubber products & 0.42 & 0 \\
\hline 356 & Plastic products & 0.36 & 0 \\
\hline 361 & Pottery, china, earthenware & 0.46 & 0 \\
\hline 362 & Glass and glass products & 0.44 & 0 \\
\hline 369 & Other non-metallic mineral products & 0.37 & 0 \\
\hline 371 & Iron and steel & 0.38 & 0 \\
\hline 372 & Non-ferrous metals & 0.33 & 1 \\
\hline 381 & Fabricated metal products & 0.45 & 0 \\
\hline 382 & Machinery, except electrical & 0.51 & 1 \\
\hline 383 & Machinery, electrical & 0.38 & 0 \\
\hline 384 & Transport equipment & 0.47 & 1 \\
\hline 385 & Professioal and scientific equipment & 0.43 & 1 \\
\hline 390 & Other manufactured products & 0.43 & 1 \\
\hline
\end{tabular}

\section{Appendix Table 1D: Is the Core Sample Representative?}

\begin{tabular}{|l|l|l|}
\hline \multicolumn{1}{|c|}{ Variable } & $\begin{array}{c}\text { Sample in } \\
\text { this paper }\end{array}$ & Larger sample \\
\hline Aid to GDP & & \\
$\quad$ Mean & $5.8 \%$ & $7.0 \%$ \\
Standard deviation & $4.6 \%$ & $5.6 \%$ \\
\hline Real GDP growth & & \\
$\quad$ Mean & $1.0 \%$ & $0.7 \%$ \\
Standard deviation & $2.3 \%$ & $2.1 \%$ \\
\hline Real value added growth in & & \\
manufacturing & & \\
Mean & $4.8 \%$ & $3.6 \%$ \\
Standard deviation & $3.5 \%$ & $3.6 \%$ \\
\hline
\end{tabular}

Core sample comprises the 33 countries for which UNIDO's disaggregate manufacturing data are available and that have aid to GDP less than 1 percent or fall in the category of low-income countries. Larger sample includes countries that satisfy the same criteria but for which data on aggregate manufacturing is available in the World Bank's World Development Indicators (it excludes 3 countries with an aid-to-GDP ratio exceeding 30 percent). 


\section{Appendix 2: An Alternative Instrument}

In order to diminish any bias from politically-motivated aid, we could try and extract the exogenous variation stemming from more "neutral" factors such as macroeconomic and budgetary conditions in the donor countries. That is, we can estimate the regression

$$
A_{d t}=\alpha_{0}+\alpha_{1} F B_{d t}+\alpha_{2} U N_{d t}+\epsilon_{d t}=\alpha^{\prime} X_{d t}+\epsilon_{d t}
$$

where $F B_{d t}$ is the overall fiscal balance as a share of GDP in donor country $\mathrm{d}$ in time period $\mathrm{t}$, and $U N_{d t}$ is the unemployment rate. The idea is that countries are more likely to be forthcoming with aid when their budgetary positions are more favorable, a factor that is likely to be exogenous to a recipient country's long run growth. The explanatory variables are obtained from the IMF's World Economic Outlook (WEO) database.

We then use the predicted value, $\hat{A}_{d t}=\alpha^{\prime} X_{d t}$, to estimate the instrument

$$
\bar{A}_{r t}=\frac{\sum_{d} G D P_{d t} \hat{A}_{d t} \cdot \hat{\theta}_{d r t}}{G D P_{r t}}
$$

The rest of the estimation is as with the instrument used in the text. 


\section{References}

Acemoglu, Daron, Simon Johnson, James A. Robinson, and Yunyong Thaicharoen, 2003, "Institutional Causes, Macroeconomic Symptoms: Volatility, Crises and Growth," Journal of Monetary Economics, No. 50, pp. 49-123.

Adam, Christopher, 2005, "Exogenous Inflows and Real Exchange Rates: Theoretical Quirk or Empirical Reality?" Peter Isard, Leslie Lipschitz, Alexandros Mourmouras, Boriana Yontcheva, (eds.), The Macroeconomic Management Of Foreign Aid, (Washington: International Monetary Fund).

Adam, Christopher, and Stephen A. O'Connell, 1999, "Aid, Taxation and Development in Sub Saharan Africa," Economics and Politics, Vol. 11, November, pp. 225-53.

Alesina, Alberto and David Dollar, 2000, "Who Gives Foreign Aid to Whom and Why?" Journal of Economic Growth, Vol. 5, No. 1, pp. 33-63.

Alesina, Alberto, and Beatrice Weder, 2002, "Do Corrupt Governments Receive Less Foreign Aid?" American Economic Review, Vol. 92, No. 4, pp. 1126-37.

Arellano, C., A. Bulir, T. Lane, L. Lipschitz, 2005, “The Dynamic Implications of Foreign Aid and Its Variability," IMF Working Paper 05/119, Washington: International Monetary Fund.

Atingi-Ego, Michael, and Rachel Sebudde, 2000, “Uganda's Equilibrium Real Exchange Rate and its Implications for Non-Traditional Export Performance," Bank of Uganda Staff Papers, Vol. 2, No. 1, pp. 1-43.

Azam, Jean-Paul, Shantayanan Devarajan, and Stephen A. O'Connell, 1999, "Aid Dependence Reconsidered," World Bank Policy Research Working Paper No. 2144.

Banerjee, Abhijit, Shawn Cole, Esther Duflo, and Leigh Linden, 2004, "Remedying Education: Evidence from two randomized experiments in India," Mimeo, MIT.

Banerjee, Abhijit and Lakshmi Iyer, 2005, "History, Institutions, and Economic performance: The Legacy of Colonial Land Tenure Systems in India," American Economic Review, pp. 1190-1213.

Barro, Robert J., and Jong-Wha Lee, 2004, "IMF Programs: Who is Chosen and What are the Effects?" mimeo.

Bauer, P.T., 1971, Dissent on Development: Studies and Debates in Development Economics, London: Weidenfeld \& Nicholson.

Berg, A., M. Hussain, S. Aiyar, S. Roache, and A. Mahone, 2005, "The Macroeconomics of Managing Increased Aid Inflows: Experiences of Low-Income Countries and Policy Implications,"'(Washington: International Monetary Fund) 
Bhagwati, Jagdish, and Padma Dasai, 1970, Planning for Industrialization, London: Oxford University Press.

Brautigam and Knack, 2004, "Foreign Aid, Institutions, and Governance in Sub-Saharan Africa," Economic Development and Cultural Change, pp. 255-85.

Bulir, A. and T.Lane, 2002, “Aid and Fiscal Management," IMF Working Paper 02/112.

Burnside, Craig and David Dollar (2000) "Aid, Policies, and Growth," American Economic Review No. 90 Vol. 4, pp. 847-68.

Clemens, Michael A., Steven Radelet and Rikhil Bhavnani, 2004, "Counting Chickens when They Hatch: The Short Term Effect of Aid on Growth," Working Paper No. 44, Center for Global Development.

Cordon and Neary, 1982, "Booming Sector and De-Industrialization in a Small Open Economy,” Economic Journal, December, Vol. 92, No. 368, pp. 825-48.

Collier, Paul, and David Dollar, 2002,"Aid Allocation and Poverty Reduction," European Economic Review, Vol. 46, No. 8, pp. 1475-1500.

Dalgaard, Carl-Johan, Henrik Hansen and Finn Tarp, 2004, "On the Empirics of Foreign Aid and Growth,” Economic Journal, Vol. 114, No. 496, pp.191-216.

Dollar, D., 1992, “Outward-oriented developing economies really do grow more rapidly: evidence from 95 LCDs, 1976-1985," Economic Development and Cultural Change, Vol. 40, pp. 523-44.

Easterly, William, 2003, “Can Foreign Aid Buy Growth?” Journal of Economic Perspectives, Vol. 17, No. 3, pp. 23-48.

Easterly, William, and Ross Levine, 2003, "Tropics, Germs, and Crops: How Endowments Influence Economic Development," Journal of Monetary Economics, Vol. 50, No. 1, pp. 3-39.

Easterly, William, Ross Levine, and David Roodman, 2004, "New Data, New Doubts: A Comment on Burnside and Dollar's Aid, Policies, and Growth," American Economic Review, forthcoming.

Elbadawi, I. A., 1999, "External Aid: Help or Hindrance to Export Orientation in Africa?" Journal of African Economics, Vol. 8, December, pp. 578-616.

Frankel, Jeffrey, 2004, "On the Yuan: The Choice between Adjustment under a Fixed Exchange Rate and the Adjustment under Flexible Rate," CESifo Economic Studies, Gerhard Illing (ed.).

Frankel, Jeffery, and David Romer, 1999, “Does Trade Cause Growth?” American Economic Review, Vol. 89, No. 3, pp. 379-99. 
Friedman, Milton, 1958, “Foreign Economic Aid," Yale Review, Vol. 47, No. 4, pp. 501-16.

Hansen, Henrik, and Finn Tarp, 2001, “Aid and Growth Regressions," Journal of Development Economics, Vol. 64. pp. 547-70.

Johnson, Simon, Jonathan Ostry, and Arvind Subramanian, 2006, "Prospects for Africa: Benchmarking the Contsraints," mimeo, International Monetary Fund, Washington D.C.

Jones, Benjamin, and Benjamin Olken, 2005, “The Anatomy of Start-Stop Growth,” NBER Working paper, No. 11528.

Knack, S., 2001, "Aid Dependence and the Quality of Governance: Cross-Country and Empirical Test," Southern Economic Journal, pp. 310-329.

Kremer, Michael, Edward Miguel, and Rebecca Thornton, 2004, "Incentives to Learn," NBER Working Paper No. W10971.

Krugman, P.R., 1987, "The Narrow Moving Band, the Dutch Disease, and the Economic Consequences of Mrs. Thatcher," Journal of Development Economics.

Krueger, A.O., 1975, The Benefits and Costs of Import Substitution in India: A Microeconomic Study (Minneapolis: University of Minnesota Press).

Nicita, Alessandro, and Marcelo Olarreaga, 2001, "Trade and Production, 1976-99," Policy Research Working Paper Series 2701, (Washington: The World Bank.).

Nyoni, Timothy, 1998, "Foreign Aid and Economic Performance in Tanzania," World Development, Vol. 26, No. 7, pp. 1235-40.

Prati, Alessandro, and Thiessy Tressel, 2006, "Aid Volatility and Dutch Disease. Is There a role for Macroeconomic Policies?" mimeo, (Washington: International Monetary Fund).

Rajan, Raghuram, and Arvind Subramanian, 2005, "Aid and Growth: What Does the CrossCountry Evidence Really Show?" NBER Working Paper 11513.

Rajan, Raghuram, and Luigi Zingales, 1998, "Financial Dependence and Growth," American Economic Review, Vol. 88, No. 3, pp.559-86.

Reinhart, Carmen, and Kenneth Rogoff, 2004, "The Modern History of Exchange Rate Arrangements," Quarterly Journal of Economics, Vol.119, No. 1, pp. 1-48.

Rodriguez, Francisco and Dani Rodrik, 1997, "Trade Policy and Economic Growth: A Skeptic's Guide to the Cross-National Evidence," in Ben Bernanke and Kenneth Rogoff (eds.) NBER Macroeconomics Manual,2000.

Roodman, David, 2004, “The Anarchy of Numbers: Aid, Development, and Cross-country Empirics," (Washington: Center for Global Development). 
Staiger, Douglas, and James Stock (1997) "Instrumental Variables Regression with Weak Instruments," Econometrica, No. 65 Vol. 3; pp. 557-86.

Subramanian, Arvind, and Utsav Kumar, 2006, "Counting Chickens before they Hatch: A Comment," mimeo, (Washington: International Monetary Fund).

Svensson, Jakob, 2003, "Why Conditional Aid Doesn't Work and What Can Be Done About It?" Journal of Development Economics, Vol. 70, No. 2, pp. 381-402.

United Nations Industrial Development Organization, 2003, Database on Industrial Statistics, United Nations, Vienna.

Van Wijnbergen, Sweder, 1986, "Macroeconomic Aspects of the effectiveness of Aid: One the Two-Gap Model, Home Goods Disequilibrium, and Real Exchange Rate Misalignment," Journal of International Economics, Vol. 21, No. 1-2, pp 123-36.

Vos, Rob, 1998, "Aid Flows and Dutch Disease in a general Equilibrium Framework for Pakistan," Journal of Policy Modelling, Vol. 20, No. 1, pp. 77-109.

World Bank, 2004, “Making Services Work for Poor People,” World Development Report:

World Bank, 1998, “Knowledge for Development," World Development Report

Yano, Makoto, and Jeffrey B. Nugent, 1999, “Aid, Nontraded Goods, and the Transfer Paradox in Small Countries," The American Economic Review, Vol. 89, No.3, pp. 431-49.

Younger, Stephen, 1992, "Aid and Dutch Disease: Macroeconomic Management When Everybody Loves You,” World Development, Vol. 20, No. 11, pp. 1587-97. 